Article

\title{
Synthesis and in Vitro Antiproliferative Evaluation of Some B-norcholesteryl Benzimidazole and Benzothiazole Derivatives
}

\section{Jianguo Cui ${ }^{1,2}$, Binbin Qi ${ }^{1}$, Chunfang Gan ${ }^{1}$, Zhipin Liu ${ }^{1}$, Hu Huang ${ }^{2}$, Qifu Lin ${ }^{2}$, Dandan Zhao ${ }^{1}$ and Yanmin Huang ${ }^{1, *}$}

1 College of Chemistry and Material Science, Guangxi Teachers Education University, Nanning 530001, China; E-Mails: cuijg1954@126.com (J.C.); 554377663@qq.com (B.Q.); ganchunfang2008@126.com (C.G.); 573052962@qq.com (Z.L.); 404045774@qq.com (D.Z.)

2 Guangxi Key Laboratory of Beibu Gulf Marine Biodiversity Conservation, Qizhou University, Qizhou 535099, China; E-Mails: mrhuanghu@126.com (H.H.); linqifu335@163.com (Q.L.)

* Author to whom correspondence should be addressed; E-Mail: huangyanmin828@163.com; Tel.: +86-771-3908065; Fax: +86-771-3908308.

Academic Editor: Khalid El Sayed

Received: 29 January 2015 / Accepted: 10 April 2015 / Published: 22 April 2015

\begin{abstract}
Taking orostanal (a compound from a Japanese marine sponge, Stelletta hiwasaensis) as a lead compound, some novel B-norcholesteryl benzimidazole and benzothiazole derivatives were synthesized. The antiproliferative activity of the compounds against human cervical carcinoma (HeLa), human lung carcinoma (A549), human liver carcinoma cells (HEPG2) and normal kidney epithelial cells (HEK293T) was assayed. The results revealed that the benzimidazole group was a better substituent than benzothiazole group for increasing the antiproliferative activity of compounds. 2-(3 $\beta^{\prime}$-Acetoxy-5 $\beta^{\prime}$ hydroxy-6'-B-norcholesteryl)benzimidazole (9b) with the structure of 6-benzimidazole displays the best antiproliferative activity to the cancer cells in all compounds, but is almost inactive to normal kidney epithelial cells (HEK293T). The assay of compound 9b to cancer cell apoptosis by flow cytometry showed that the compound was able to effectively induce cancer cell apoptosis. The research provided a theoretical reference for the exploration of new anti-cancer agents and may be useful for the design of novel chemotherapeutic drugs.
\end{abstract}

Keywords: cholesterol; B-norcholesteryl benzimidazoles; B-norcholesteryl benzothiazoles; antiproliferative activity; apoptosis 


\section{Introduction}

Cancer is the leading cause of death in economically developed countries and the second leading cause of death in developing countries [1]. WHO reported that the incidence of cancer will increase by $50 \%$, and the global annual increase of the number of cancer patients will reach 15,000,000 in 2020. So, finding novel chemotherapeutic agents with excellent antiproliferative activity and high therapeutic compounds remain an important target for scientists [2].

The discovery of new compounds from natural sources has been very important in pharmacologic science research. The past decade has witnessed an increase in the number of compounds from the screening of diverse marine invertebrates, such as soft corals, sponges and tunicates. In 2001, a novel sterol, named orostanal (1) (Figure 1), possessing a contracted cyclopentane B-ring was isolated from a Japanese marine sponge, Stelletta hiwasaensis. Orostanal induced apoptosis in HL-60 cells at $10 \mu \mathrm{g} / \mathrm{mL}$, and inhibited 50\% cell growth at $1.7 \mu \mathrm{M}$ [3]. After that, another novel 5(6-7)abeo-sterol named parguesterol B (2) was obtained from the Caribbean Sea sponge Svenzea zeai, and it was a moderately strong anti-tuberculosis molecule with a MIC value of $7.8 \mu \mathrm{g} / \mathrm{mL}$ [4].

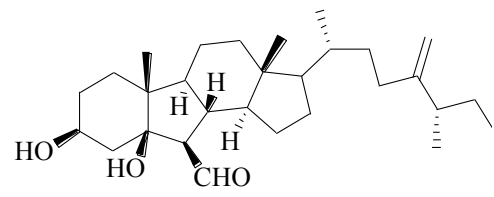

Orostanal (1)

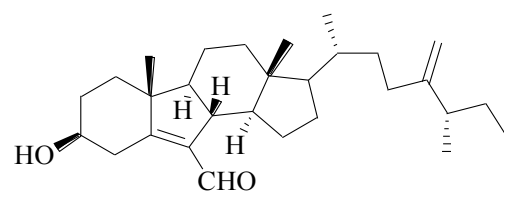

Parguesterol B (2)

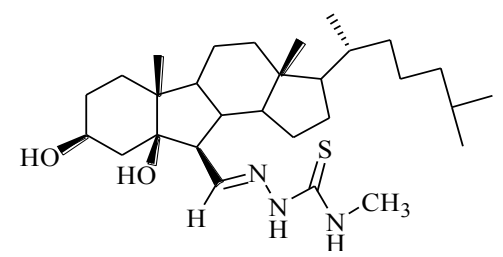

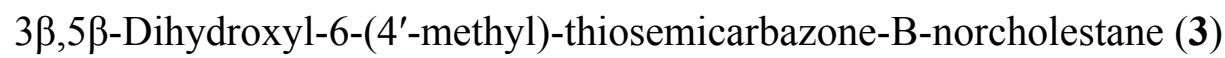

Figure 1. The structures of compounds $\mathbf{1}-\mathbf{3}$.

Since compound 1 displays an excellent antiproliferative activity by inducing the apoptosis of tumor cell, it aroused our great interest to design and synthesize some steroidal compounds with 6,5,6,5 fused rings and assay their antiproliferative activity. In previous work, taking orostanal as a lead compound, we had prepared a series of analogs of compound $\mathbf{1}$ or $\mathbf{2}$ with different substituted groups and various side chains, and evaluated their antiproliferative activities $[5,6]$. The results showed that the presence of a cholesterol-type side chain was very important in determining the cytotoxicity of these compounds, and the presence of a thiosemicarbazone group at the C-6 position of steroid nucleus could enhance the antiproliferative activity of the compounds. For example, compound $\mathbf{3}$ exhibited excellent antiproliferative activities with an $\mathrm{IC}_{50}$ value of 13.8 and $5.4 \mu \mathrm{M}$ against SGC-7901 (human ventriculi carcinoma) and HeLa (human cervical carcinoma) cells [7].

Heterosteroids have been accredited with a great amount of attention over the years by medicinal chemists for drug discovery. The incorporation of a heterocyclic ring or a heteroatom in the steroidal skeleton affects the chemical properties of a steroid and often results in useful alterations in its biological activities [8,9]. Some heterosteroids display an excellent anticancer activitiy, e.g., anticancer 
agents like 2-methoxyestradiol [10], exemestane [11], estramustine phosphate sodium [12] and abiraterone [13]. So far, the steroids containing heterocycles had been widely explored and reported [14]. Literatures suggested that such compounds displayed distinct cytotoxicity against cancer cell lines [15-19].

In order to obtain biologically potent anticancer compounds with diverse structures, as an extension of our previous work, a series of B-norsteroidal compounds possessing a 6,5,6,5 fused ring and the structure of 6-benzimidazole or 6-benzothiazole had been prepared starting from cholesterol in the present study. Meanwhile the antiproliferative activity of the compounds in vitro was evaluated further.

\section{Results and Discussion}

\subsection{Chemistry}

Scheme 1 outlines the synthetic procedure of B-norcholesteryl benzimidazole compounds (7-11). Compound 6 was prepared according to Gan, C.F. [5]. The configurations of C-5 and C-7 in compound 6 had been described in references [20-22]. The reaction of compound 6 with $O$-phenylenediamine afforded a corresponding benzimidazole group in the 6-position of steroidal nucleus [23]. To investigate the effect of various substituent groups in benzene ring on the antiproliferative activity of compounds, compounds (7-11) were synthesized by the reaction of $\mathbf{6}$ with different $O$-phenylenediamine derivatives. Their structures were confirmed on analytical and spectral data. In the NMR spectrum, resonances signals of Ar-H at 6.93, 7.22, $7.44 \mathrm{ppm}$ and Ar-C at 160.7-110.0 ppm proved the formation of benzimidazole in compound $7 \mathbf{a}$.

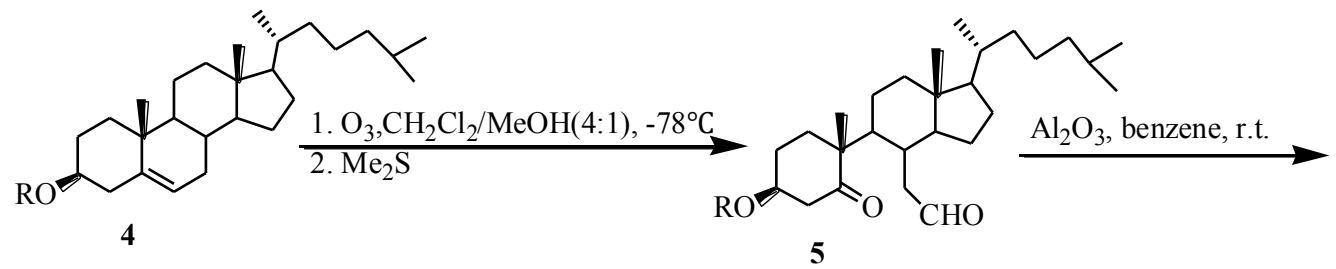

4a: $\mathrm{R}=\mathrm{H}$

4b: $\mathrm{R}=\mathrm{Ac}$

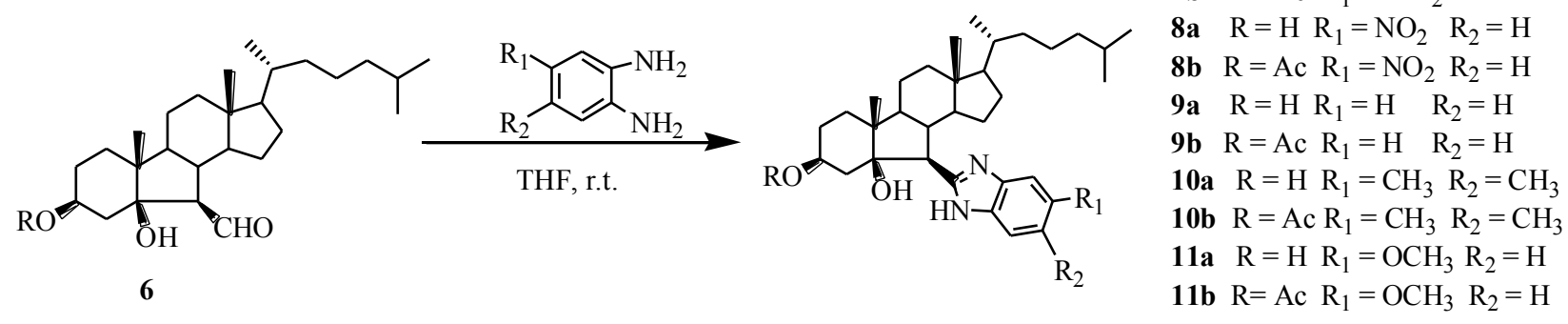

$$
\begin{aligned}
& \text { 7a } R=H \quad R_{1}=F \quad R_{2}=H \\
& \text { 7b } R=A c \quad R_{1}=F \quad R_{2}=H \\
& \text { 8a } R=H \quad R_{1}=N_{2} \quad R_{2}=H \\
& \text { 8b } R=A c R_{1}=N_{2} \quad R_{2}=H \\
& \text { 9a } R=H \quad R_{1}=H \quad R_{2}=H \\
& \text { 9b } R=A c R_{1}=H \quad R_{2}=H \\
& \text { 10a } R=H \quad R_{1}=C_{3} \quad R_{2}=C_{3} \\
& \text { 10b } R=A c R_{1}=C_{3} \quad R_{2}=C H_{3} \\
& \text { 11a } R=H \quad R_{1}=O C H_{3} \quad R_{2}=H \\
& \text { 11b } R=A c R_{1}=O_{3} \quad R_{2}=H
\end{aligned}
$$

Scheme 1. Synthesis of compounds 7-11.

However, when compound 6 reacted with 4-trifluoromethyl-O-phenylenediamine, the anticipated compound, 2-(3 $\beta^{\prime}, 5 \beta^{\prime}$-dihydroxy-6'-B-norcholesteryl)-5-trifluoromethylbenzimidazole was not produced. Interestingly, we obtained compound $\mathbf{1 2}$ possessing an isoxazolidine ring structure (Scheme 2). Because the nucleophilicity of $2^{\prime}-\mathrm{NH}_{2}$ is largely decreased due to a negative inductive effect of trifluoromethyl group, it cannot form the structure of benzimidazole, and compound $\mathbf{1 2}$ is generated. 
The structure of $\mathbf{1 2}$ was confirmed by analysis of ${ }^{1} \mathrm{H},{ }^{13} \mathrm{C}$ NMR, DEPT135/90 and HMQC (see Supplementary Information).

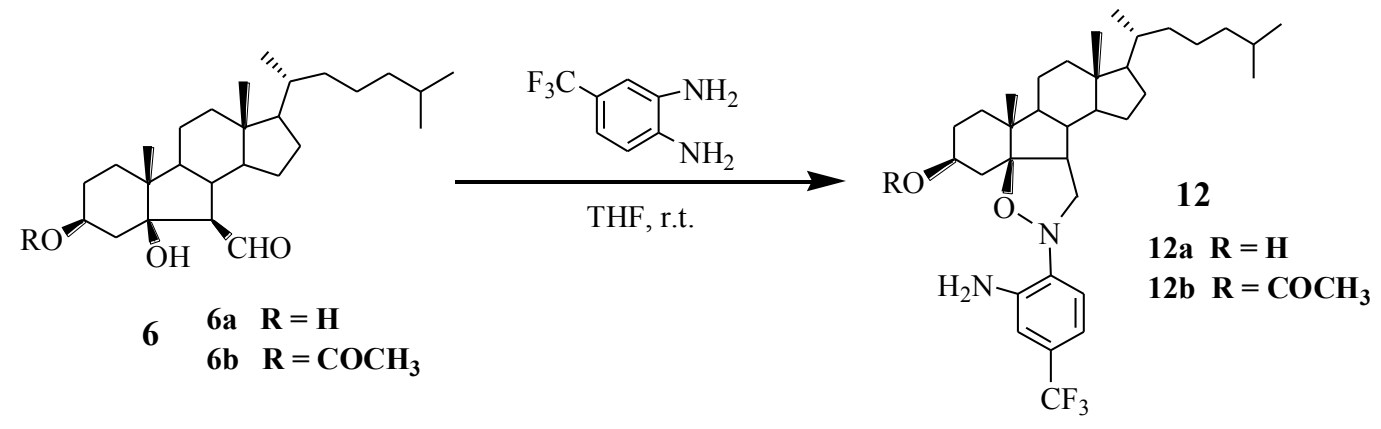

Scheme 2. Synthesis of compounds $\mathbf{1 2}$.

A proposed mechanism for the formation of compounds $\mathbf{1 2}$ is shown in Scheme 3. First, 1-NH2 of 4-trifluoromethyl-O-phenylenediamine attacks 6-aldehyde group of compound $\mathbf{6}$ to afford the intermediate A (Because of electron-withdrawing effect of trifluoromethyl, the nucleophilicity of $2-\mathrm{NH}_{2}$ was decreased largely.). Subsequently, the coupling of imine with 5-hydroxyl in intermediate A gives compound 12 via migration of a hydrogen on hydroxyl.

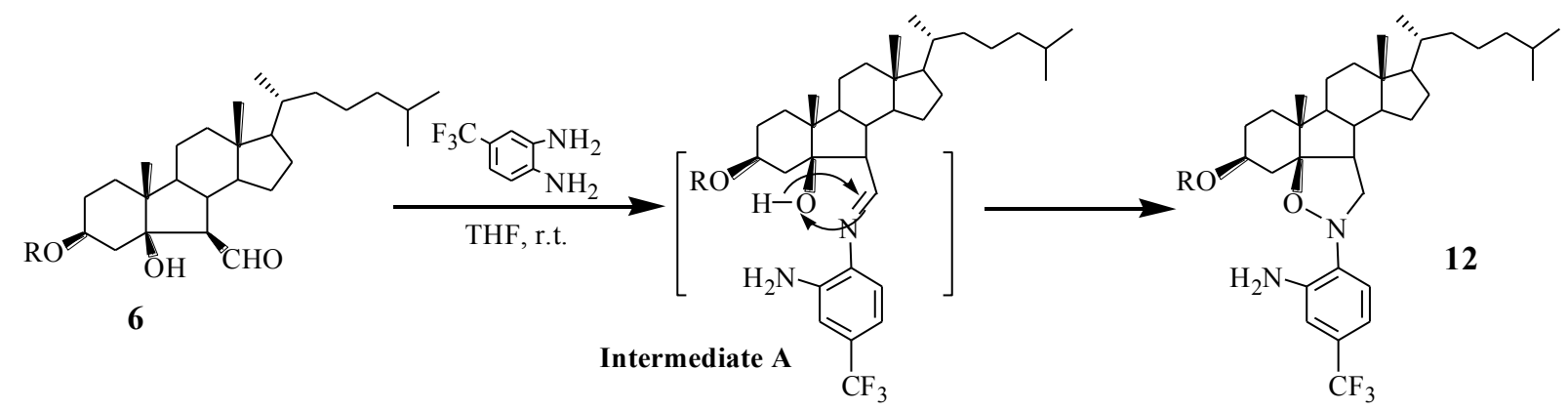

Scheme 3. The mechanism of formation of compound 12.

In order to investigate the effect of S-containing benzimidazole on the antiproliferative activity, we prepared B-norcholesteryl benzothiazoles (13) by reacting compound 6a with 2-aminothiophenol (Scheme 4). The structure of $\mathbf{1 3}$ was confirmed by analysis of IR, NMR and HRMS.

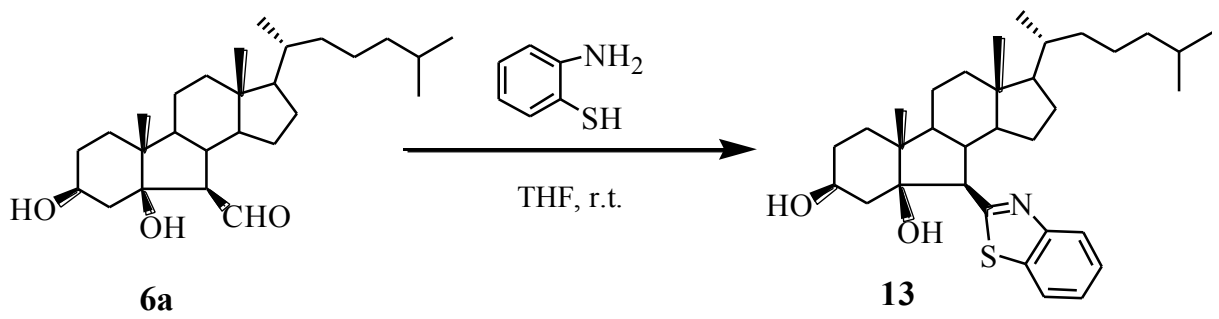

Scheme 4. Synthesis of compound 13.

Last, in order to determine the effect of benzene ring in benzimidazole on the cytotoxicity of compounds, we hoped to prepare compound $\mathbf{1 4}$ possessing a structure of pyridine ring but the 
anticipated compound 14 was not formed (Scheme 5). However, we obtained compound 15 with a structure of imine. The structure of $\mathbf{1 5}$ was confirmed by analysis of IR, NMR and HRMS.

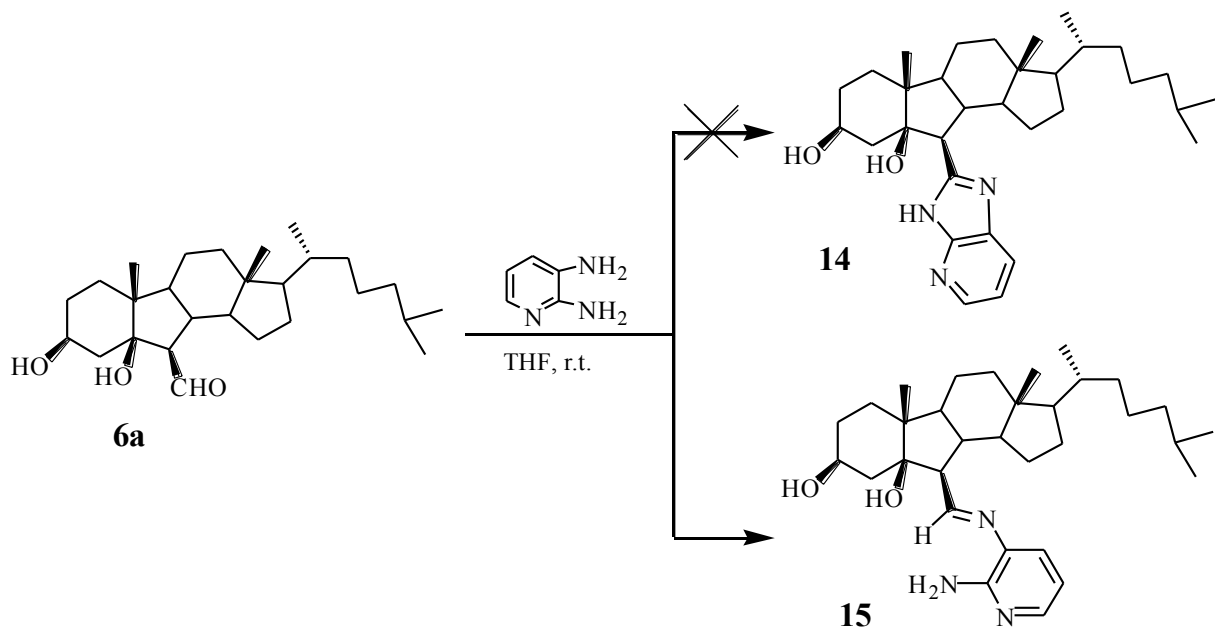

Scheme 5. Synthesis of compound 15.

\subsection{Biological Results and Discussion}

Lung cancer and liver cancer are a main cause of death in cancer patients. To evaluate the antiproliferative activity of the new compounds, we determined their IC50 values on A549 (human lung carcinoma), HEPG2 (human liver carcinoma) and HeLa (human cervical carcinoma) using a MTT assay, and non-cancer cells HEK293T (Normal Kidney Epithelial Cells) were chosen as a control. MTT is a compound that can be taken up by viable cells and reduced by a mitochondrial dehydrogenase forming a formazan product in living cells. The absorbance of the formazan at $492 \mathrm{~nm}$ is in linear proportion to cell numbers. The results were summarized as $\mathrm{IC}_{50}$ values (concentration of a compound allowing survival of $50 \%$ of the cells in a population) in $\mu \mathrm{mol} / \mathrm{L}$ in Table 1.

Table 1. In vitro antiproliferative activities ( $\mathrm{IC}_{50}$ in $\mu \mathrm{mol} / \mathrm{L}$ ) of compounds $\mathbf{7 - 1 5}$.

\begin{tabular}{ccccc}
\hline \multirow{2}{*}{ Compounds } & \multicolumn{4}{c}{ Cells } \\
\cline { 2 - 5 } & HeLa & A549 & HEPG2 & HEK293T \\
\hline $\mathbf{7 a}$ & 4.2 & 66.7 & $>40$ & 19.1 \\
$\mathbf{7 b}$ & 15.9 & 28.2 & 21.2 & 20.3 \\
$\mathbf{8 a}$ & 3.6 & 47.2 & 21.8 & 37.2 \\
$\mathbf{8 b}$ & 31.2 & 50.6 & 30.3 & $>80$ \\
$\mathbf{9 a}$ & 4.9 & 61.2 & 29.6 & 53.3 \\
$\mathbf{9 b}$ & 4.7 & 11.9 & 4.2 & $>80$ \\
$\mathbf{1 0 a}$ & 7.5 & 13.1 & 4.5 & $>80$ \\
$\mathbf{1 0 b}$ & 2.2 & 31.2 & $>40$ & $>80$ \\
$\mathbf{1 1 a}$ & 7.5 & 14.0 & 8.4 & $>80$ \\
$\mathbf{1 1 b}$ & 11.8 & $>80$ & $>40$ & $>80$ \\
$\mathbf{1 2 a}$ & 16.6 & 27.0 & 12.2 & $>100$ \\
$\mathbf{1 2 b}$ & 3.7 & $>80$ & $>80$ & $>100$ \\
$\mathbf{1 3}$ & 22.0 & $>80$ & $>80$ & 58.3 \\
$\mathbf{1 5}$ & 20.6 & $>80$ & $>80$ & $>80$ \\
\hline
\end{tabular}


As showed in Table 1, B-norcholesteryl benzimidazole derivatives (7-11) exhibited an excellent antiproliferative activity against HeLa cells. Except for compounds $\mathbf{7 b}, \mathbf{8 b}$ and $\mathbf{1 1 b}$, the IC50 values of all compounds are under $10 \mu \mathrm{M}$. Thereinto, the most active compounds were $7 \mathbf{a}, 8 \mathbf{8 a}, 9 \mathbf{a}, 9 \mathbf{b}$ and $10 \mathbf{a}$ (IC50 values: 4.2, 3.6, 4.9, 4.7 and 2.2, respectively). Obviously, compound $9 \mathbf{b}$ with the structure of 6-benzimidazole displayed the best antiproliferative activity against A549 and HEPG2 cells while compound 10b showed the best activity against HeLa cells in all compounds. Among all compounds synthesized, compound 9b with benzimidazole, 10a and 11a with electron-donating groups in the benzimidazole displayed excellent cytotoxicity for HEPG2 cells (IC50: 4.2, 4.5 and 8.4, respectively).

After an electron-withdrawing group was introduced into the skeleton of benzimidazole, the cytotoxicity of the compounds $\mathbf{7 b}-\mathbf{8 b}$ possessing 5-fluoro and 5-nitro resulted in slightly decreased. However, compounds 10a, 10b and 11a with electron-donating groups in the benzene ring showed a similar cytotoxicity compare with compounds 9a and 9b. Interestingly, except compound 9a, compound $\mathbf{9 b}$ and compounds 10-11 with the electron-donating groups were almost inactive to normal kidney epithelial cells (HEK293T), but compounds $\mathbf{7}$ and 8a with the electron-withdrawing groups showed distinct cytotoxicity to same kind of cells.

After the 3-hydroxyl group on 8a was transformed into 3-acetoxyl, the antiproliferative activity of compound $\mathbf{8 b}$ against these cells decreased greatly, suggesting the importance of the hydroxyl group in the compound 8. However, after the 3-hydroxyl group in 9a was transformed into 3-acetoxyl, the antiproliferative activity of forming compound $\mathbf{9 b}$ obtained a prominent increase against the cancer cells and an obvious decrease on normal kidney epithelial cells. These results demonstrated that compound $9 \mathrm{~b}$ based on the 3-acetoxyl and 6-benzimidazole was a potent antiproliferative agent.

Compound 12a bearing an isoxazolidine ring structure displayed also distinct cytotoxicity against these cancer cells. However, compound 12b showed an excellent selective cytotoxicity against HeLa cells with an $\mathrm{IC}_{50}$ value of $3.7 \mu \mathrm{M}$, and was almost inactive on other cancer cells. Both of $\mathbf{1 2 a}$ and $\mathbf{1 2 b}$ were inactive on normal kidney epithelial cells.

Apparently, after the $\mathrm{N}$ atom of benzimidazole was substituted by $\mathrm{S}$ atom, the cytotoxic activity of the forming compound 13 was markedly decreased (compare 9a and 13). The results demonstrate that benzimidazole group is a better substituent than benzothiazole group for increasing the antiproliferative activity of compounds and suggest that the analogs based on the 6-benzimidazole scaffold may constitute a novel class of antiproliferative agents, which deserve further study. Obviously, compound 15 with the structure of pyridine ring didn't display distinct cytotoxicity against all these cells except HeLa cells.

The Selectivity Index (SI) was defined as the ratio of the cytotoxicity of a compound with respect to normal cells (IC50 HEK293T) versus cancer cells and used to determine the criterion of effectiveness of the compounds. The SI values of the compounds are listed in Table 2.

One important criterion for a therapeutic drug for cancer is to have minimal or no side effects to normal body cells of patients undergoing chemotherapy. Taking into account that a higher SI corresponds to greater overall anticancer activity, we can identify the leading compounds as 9b, 10a and 11a (SI values for HeLa cells: 17.0, 10.7, 10.7; A549 cells: 6.7, 6.1, 5.7; HEPG2: 19.0, 17.8, 9.5). Meanwhile, compound 10b displayed the best excellent selective inhibition against HeLa cells, and the SI was 36.4. So, comparison of the cytotoxicity of the compounds with the SI values suggested that the compounds 9b, 10a and 11a may be potent anticancer agents and compounds 10b and 12b are excellent inhibitors against human cervical carcinoma (HeLa), which deserve further study. 
Table 2. SI values of the compounds $\mathbf{7 - 1 5}$.

\begin{tabular}{cccc}
\hline Compounds & SI $_{\text {HeLa }}$ & SI $_{\text {A549 }}$ & SI HEPG2 $^{\text {Ha }}$ \\
\hline $\mathbf{7 a}$ & 4.5 & - & - \\
$\mathbf{7 b}$ & 1.3 & - & - \\
$\mathbf{8 a}$ & 10.3 & - & 1.7 \\
$\mathbf{8 b}$ & 2.6 & 1.6 & 2.6 \\
$\mathbf{9 a}$ & 10.9 & - & 1.8 \\
$\mathbf{9 b}$ & 17.0 & 6.7 & 19.0 \\
$\mathbf{1 0 a}$ & 10.7 & 6.1 & 17.8 \\
$\mathbf{1 0 b}$ & 36.4 & 2.6 & - \\
$\mathbf{1 1 a}$ & 10.7 & 5.7 & 9.5 \\
$\mathbf{1 1 b}$ & 6.8 & - & - \\
$\mathbf{1 2 a}$ & 6.0 & 3.7 & 8.2 \\
$\mathbf{1 2 b}$ & 27.0 & - & - \\
$\mathbf{1 3}$ & 2.7 & - & - \\
$\mathbf{1 5}$ & 3.9 & - & - \\
\hline
\end{tabular}

A comparison of the structures of the synthesized compounds with pronounced biological activity makes it possible to identify some structure/biological activity relationships for these B-norcholesteryl benzimidazole and benzothiazole derivatives:

(1) The 6-benzimidazole group is a better substituent than 6-benzothiazole group for increasing the antiproliferative activity of compounds (compare 9a and 13).

(2) The presence of electron-withdrawing groups in the benzimidazole will decrease the cytotoxicity of the compounds and electron-donating groups show not an obvious effect for cytotoxicity of compounds (compare $7 \mathbf{b}, \mathbf{8 b}$ and $9 \mathbf{b}$ or $9 \mathbf{a}, \mathbf{1 0 a}$ and $11 \mathbf{a}$ ).

(3) Introduction of an isoxazolidine ring joined with ring B or an 6-imine moiety cannot increased the cytotoxicity of the compounds (compare $7 \mathbf{a}$ and 12a, 12b). The introduction of pyridine ring in benzimidazole deceases the cytotoxicity of the compound on HeLa and HEPG2 cells (compare 9a, 12a and 15).

To further disclose the molecular mechanism by which the compounds inhibit cancer cell proliferation, the HeLa cells were treated with compounds $9 \mathbf{b}, \mathbf{1 0 a}$ and 11a, and Annexin V assay was performed. The translocation of membrane phospholipid phosphatidylserine (PS) from the inner to the outer leaflet of the plasma membrane is an early event of cell apoptosis. Annexin $\mathrm{V}$ is a $35-36 \mathrm{kD} \mathrm{Ca}{ }^{2+}$ dependent, phospholipid-binding protein that has a high affinity for PS. Therefore, FITC-conjugated Annexin V is commonly used to determine apoptotic cells at an early stage. As shown in Figure 2, treatment with $5 \mu \mathrm{M}$ of $\mathbf{9 b}, \mathbf{1 0 a}$ and $\mathbf{1 1 a}$ resulted in $54.2 \%, 54.0 \%$ and $65.1 \% \mathrm{PI} /$ Annexin $\mathrm{V}$ double-labeled apoptotic cells after $24 \mathrm{~h}$ incubation (the lower right quadrant and the upper right quadrant which contains early and late apoptotic cells, respectively), and necrotic cells are only $0.43 \%$, $0.36 \%$ and $0.67 \%$ (the upper left quadrant), suggesting these compounds are potent apoptotic inducers in cervical carcinoma cells. There into, compound 11a is more potent in induction of apoptosis in HeLa cells (Compare 11a with $\mathbf{9 b}$ and 10a). 


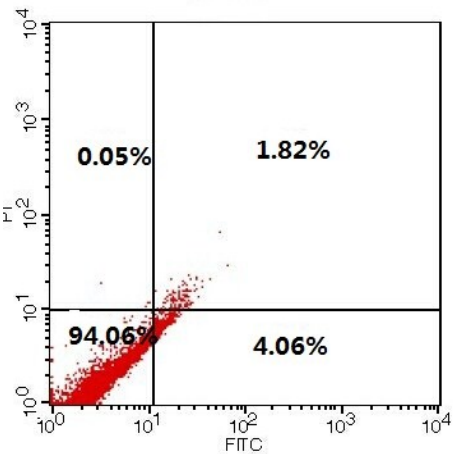

Control

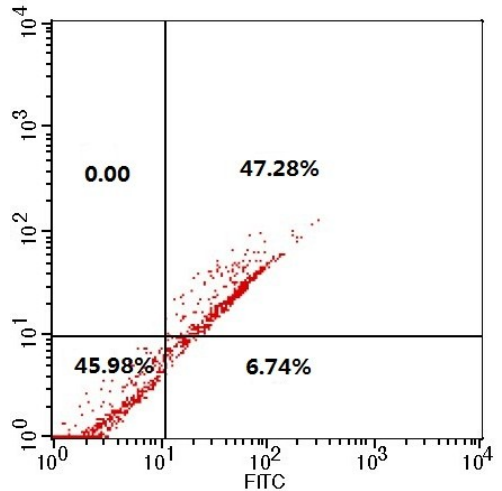

Com. 10a $(5 \mu \mathrm{M})$

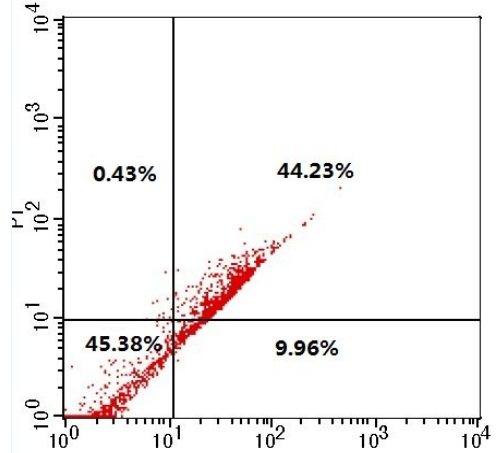

Com. $9 b(5 \mu \mathrm{M})$

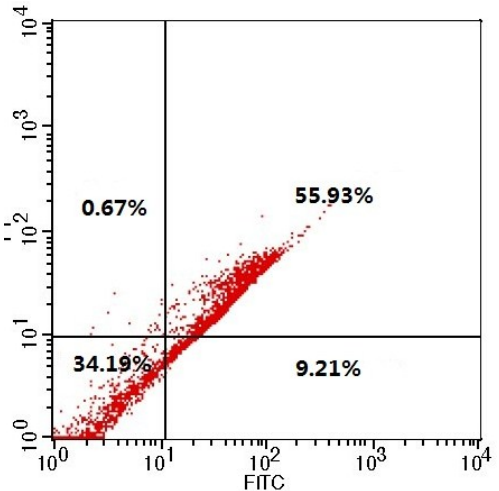

Com. 11a $(5 \mu \mathrm{M})$

Figure 2. HeLa cells were double-stained with annexin V/PI and analyzed by flow cytometry. Treatment with compounds $9 \mathrm{~b}, \mathbf{1 0 a}$ and 11a $(5 \mu \mathrm{M})$ for $24 \mathrm{~h}$ induced apoptosis of HeLa cells.

Similar results were observed after HeLa cells were treated with compounds $9 \mathbf{b}$ and 10a in a dose dependent manner (Figures 3 and 4). Treatment with $5 \mu \mathrm{M}$ of $\mathbf{9 b}$ for $24 \mathrm{~h}$ resulted in $54.2 \%$ $\mathrm{PI} /$ Annexin V double-labeled apoptotic cells while $10 \mathrm{a}$ could produce $78.4 \%$ in $10 \mu \mathrm{M}$ condition.

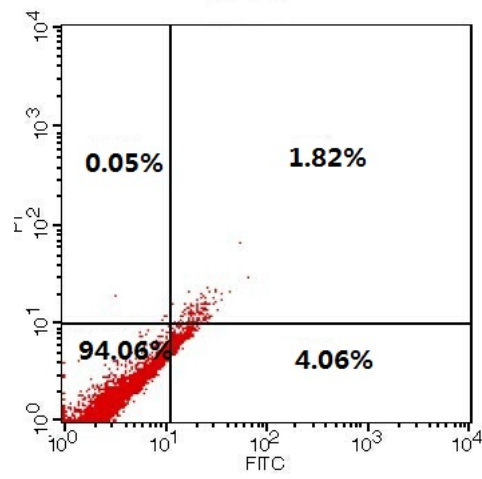

Control

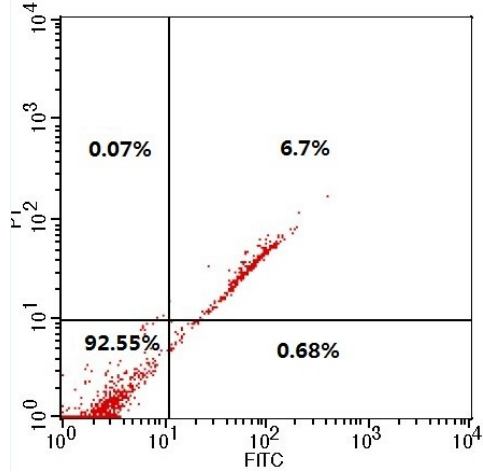

Com. 9b $(2.5 \mu \mathrm{M})$

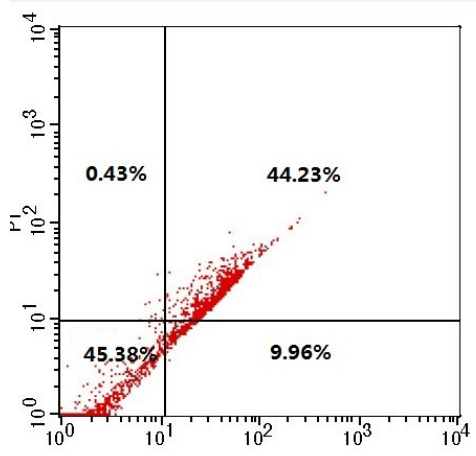

Com. 9b $(5 \mu \mathrm{M})$

Figure 3. Dose depended apoptosis induced by compound $\mathbf{9 b}$ for $24 \mathrm{~h}$. 


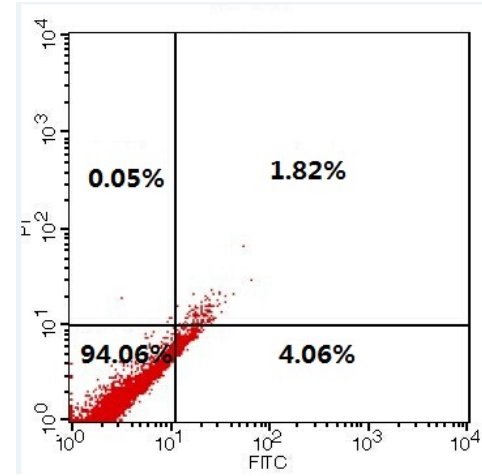

Control

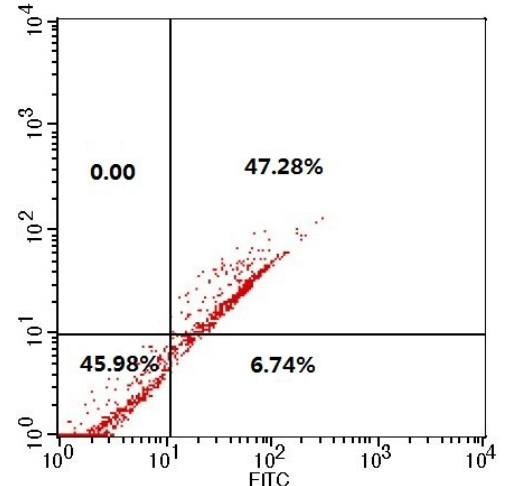

Com. 10a $(5 \mu \mathrm{M})$

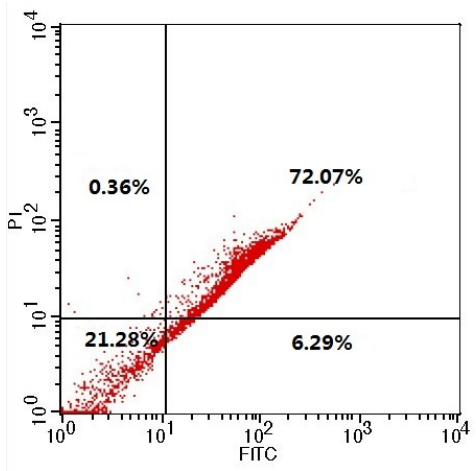

Com. 10a $(10 \mu \mathrm{M})$

Figure 4. Dose depended apoptosis induced by compound 10a for $24 \mathrm{~h}$.

\section{Experimental Section}

\subsection{Chemistry}

The sterols were purchased from Sinopharm Chemical Reagent Co., Ltd, Shanghai, China. All chemicals and solvents were analytical grade. Melting points were determined on an $\mathrm{X}_{4}$ apparatus (Beijing Tech Instrument Co. Ltd., Beijing, China) and were uncorrected. Infrared spectra were measured with a Thermo Scientific Nicolet IS-10 Spectrophotometer (Thermo Fisher Scientific, New York, NY, USA). The ${ }^{1} \mathrm{H}$ and ${ }^{13} \mathrm{C}$ NMR spectra were recorded in $\mathrm{CDCl}_{3}$ on a Bruker AV-600 spectrometer at working frequencies 600 and $150 \mathrm{MHz}$, and a Bruker AV-300 spectrometer at working frequencies 300 and $75 \mathrm{MHz}$, respectively. Chemical shifts are expressed in parts per million $(\delta)$ values and coupling constants $(J)$ in Hertz. HREIMS was measured on an Agilent 6210 TOFMS instrument (Agilent Technologies, Palo Alto, CA, USA). The cell proliferation assay was undertaken by a MTT method using 96-well plates on a MLLTISKAN MK3 analysis spectrometer (Thermo Scientific, Shanghai, China). Annexin V assay was performed using FACS Calibur flow cytometry (Becton Dickinson, Biosciences, Franklin Lakes, NJ, USA).

Compound 6 was prepared according to the method in reference [5].

\subsubsection{General Procedure for the Synthesis of Compounds 7-11}

$O$-Phenylenediamine derivative $(1.6 \mathrm{mmol})$ was added to a solution of compound $\mathbf{6}(1.0 \mathrm{mmol})$ in THF $(50 \mathrm{~mL})$. The solution was stirred for $8-24 \mathrm{~h}$ at room temperature until no starting material was observed (the progress of the reaction was monitored by TLC, petroleum ether/ethyl acetate $=2: 1$ ). Then the reaction was stopped and the majority of solvent was evaporated under reduced pressure. The residue was purified by flash chromatography on silica gel (300-400 mesh) to afford the corresponding target products $\mathbf{7 - 1 1}$.

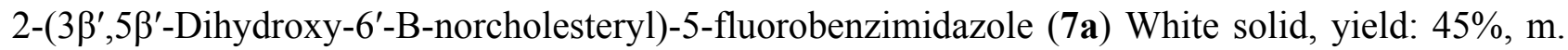
p. $139-140{ }^{\circ} \mathrm{C}$. IR (KBr) v/cm ${ }^{-1}: 3252,2945,1626,1599,1524,1444,1382,1142 ;{ }^{1} \mathrm{H} \mathrm{NMR}\left(\mathrm{CDCl}_{3}\right.$, $300 \mathrm{MHz}) \delta$ : $0.64\left(3 \mathrm{H}, \mathrm{s}, 18^{\prime}-\mathrm{CH}_{3}\right), 0.85\left(6 \mathrm{H}, \mathrm{d}, J=6.6,26^{\prime}-\right.$ and $\left.27^{\prime}-\mathrm{CH}_{3}\right), 0.91(3 \mathrm{H}, \mathrm{d}, J=6.3$, $\left.21^{\prime}-\mathrm{CH}_{3}\right), 1.06\left(3 \mathrm{H}, \mathrm{s}, 19^{\prime}-\mathrm{CH}_{3}\right), 2.16-2.04\left(2 \mathrm{H}, \mathrm{m}, \mathrm{C} 8^{\prime}-\mathrm{H}\right.$ and $\left.\mathrm{C}^{\prime}-\mathrm{H}\right), 2.70\left(1 \mathrm{H}, \mathrm{d}, J=10.8, \mathrm{C} 7^{\prime}-\mathrm{H}\right)$, $3.89(1 \mathrm{H}$, br s, C3'-H), $6.93(1 \mathrm{H}, \mathrm{td}, J=9.6,2.4,6-\mathrm{ArH}), 7.22(1 \mathrm{H}, \mathrm{d}, J=8.7,7-\mathrm{ArH}), 7.44(1 \mathrm{H}, \mathrm{dd}$, 
$J=8.4,4.5,4-\mathrm{ArH}) ;{ }^{13} \mathrm{C} \mathrm{NMR}\left(\mathrm{CDCl}_{3}, 75 \mathrm{MHz}\right) \delta: 160.7$ (2-C), 157.6 (5-C), 156.8 (8-C and 9-C), 110.3 (6-C and 7-C), 110.0 (4-C), 82.3 (5'-C), 66.9 (3'-C), 56.1 (17'-C), 55.4 (14'-C), 55.0 (7'-C), 54.6 (9'-C), 45.3 (13'-C), 45.2 (12'-C), 44.5 (24'-C), 42.3 (10'-C), 39.6 (8'-C), 39.4 (4'-C), 36.2 (22'-C), 35.5 (20'-C), 31.6 (1'-C), 28.4 (16'-C), 28.3 (25'-C), 28.0 (15'-C), 24.0 (2'-C), 23.8 (23'-C), 22.8 (26-C), 22.5 (27-C), 21.7 (11-C), 18.8 (21-C), 17.6 (19-C), 12.4 (18-C); HREIMS m/z: $525.3843[\mathrm{M}+\mathrm{H}]^{+}$ (calcd. for $\mathrm{C}_{33} \mathrm{H}_{50} \mathrm{FN}_{2} \mathrm{O}_{2}, 525.3856$ ).

2-(3 $\beta^{\prime}$-Acetoxy-5 $\beta^{\prime}$-hydroxy-6'-B-norcholesteryl)-5-fluorobenzimidazole (7b) Yellow oil, yield: $69 \%$. IR ( $\mathrm{KBr}) v / \mathrm{cm}^{-1}: 3274,2942,1729,1534,1464,1237,1018 ;{ }^{1} \mathrm{H}$ NMR $\left(\mathrm{CDCl}_{3}, 600 \mathrm{MHz}\right) \delta$ : $0.56\left(3 \mathrm{H}, \mathrm{s}, 18^{\prime}-\mathrm{CH}_{3}\right), 0.83\left(6 \mathrm{H}, \mathrm{d}, J=4.2,26^{\prime}-\right.$ or $\left.27^{\prime}-\mathrm{CH}_{3}\right), 0.89\left(3 \mathrm{H}, \mathrm{d}, J=5.4,21^{\prime}-\mathrm{CH}_{3}\right), 1.07(3 \mathrm{H}$, s, 19'- $\left.\mathrm{CH}_{3}\right), 1.74\left(3 \mathrm{H}, \mathrm{s}, \mathrm{COCH}_{3}\right), 2.28\left(1 \mathrm{H}, \mathrm{q}, J=10.8, \mathrm{C} 8^{\prime}-\mathrm{H}\right), 2.95\left(1 \mathrm{H}, \mathrm{d}, J=11.4, \mathrm{C}^{\prime}-\mathrm{H}\right), 4.88$ $\left(1 \mathrm{H}, \mathrm{m}, \mathrm{C} 3^{\prime}-\mathrm{H}\right), 6.89(1 \mathrm{H}, \mathrm{t}, J=8.4,6-\mathrm{ArH}), 7.23(1 \mathrm{H}, \mathrm{d}, J=7.8,7-\mathrm{ArH}), 7.44(1 \mathrm{H}, \mathrm{s}, 4-\mathrm{ArH}) ;{ }^{13} \mathrm{C}$ NMR $\left(\mathrm{CDCl}_{3}, 150 \mathrm{MHz}\right) \delta$ : 170.8 (3'-C=O), 160.8 (2-C), 157.7 (5-C), 155.9 (8-C and 9-C), 110.3 (6-C and 7-C), 109.9 (4-C), 81.4 (5'-C), 69.7 (3'-C), 55.7 (17'-C), 55.5 (14'-C), 54.3 (9'-C), 44.7 (12'-C), 44.4 (13'-C), 44.3 (10'-C), 39.8 (24'-C), 39.4 ( $\left.8^{\prime}-\mathrm{C}\right), 38.6$ (4'-C), 36.2 (22'-C), 35.4 (20'-C), 32.8 (1'-C), 28.5 (16'-C), 28.0 (25'-C), 25.3 (15'-C), 24.2 (2'-C), 23.7 (23'-C), 22.8 (26'-C), 22.5 (27'-C), 21.9 $\left(\mathrm{COCH}_{3}\right), 21.0\left(11^{\prime}-\mathrm{C}\right), 18.8\left(21^{\prime}-\mathrm{C}\right), 18.4\left(19^{\prime}-\mathrm{C}\right), 12.4\left(18^{\prime}-\mathrm{C}\right)$; HREIMS m/z: $567.3951[\mathrm{M}+\mathrm{H}]^{+}$ (calcd. for $\mathrm{C}_{35} \mathrm{H}_{52} \mathrm{FN}_{2} \mathrm{O}_{3}, 567.3962$ ).

2-(3 $\beta^{\prime}, 5 \beta^{\prime}$-Dihydroxy-6'-B-norcholesteryl)-5-nitrobenzimidazole (8a) Yellow oil, yield: 78\%. IR (KBr) $v / \mathrm{cm}^{-1}: 3369,2935,1587,1517,1462,1317,1165,1070 ;{ }^{1} \mathrm{H}$ NMR $\left(\mathrm{CDCl}_{3}, 300 \mathrm{MHz}\right) \delta: 0.65$ $\left(3 \mathrm{H}, \mathrm{s}, 18^{\prime}-\mathrm{CH}_{3}\right), 0.87\left(6 \mathrm{H}, \mathrm{d}, J=6.3,26^{\prime}-\right.$ and $\left.27^{\prime}-\mathrm{CH}_{3}\right), 0.93\left(3 \mathrm{H}, \mathrm{d}, J=6.3,21^{\prime}-\mathrm{CH}_{3}\right), 1.09(3 \mathrm{H}, \mathrm{s}$, $\left.19^{\prime}-\mathrm{CH}_{3}\right), 2.16-2.05\left(1 \mathrm{H}, \mathrm{m}, \mathrm{C} 8^{\prime}-\mathrm{H}\right.$ and $\left.\mathrm{C}^{\prime}-\mathrm{H}\right), 2.72\left(1 \mathrm{H}, \mathrm{d}, J=10.5, \mathrm{C}^{\prime}-\mathrm{H}\right), 4.00-3.90\left(1 \mathrm{H}, \mathrm{m}, \mathrm{C} 3^{\prime}-\mathrm{H}\right)$, $6.95(1 \mathrm{H}, \mathrm{td}, J=9.6,2.1,7-\mathrm{ArH}), 7.24(1 \mathrm{H}, \mathrm{dd}, J=7.8,6-\mathrm{ArH}), 7.45(1 \mathrm{H}, \mathrm{s}, 4-\mathrm{ArH}) ;{ }^{13} \mathrm{C} \mathrm{NMR}$ $\left(\mathrm{CDCl}_{3}, 75 \mathrm{MHz}\right) \delta$ : 160.8 (2-C), 157.7 (5-C), 156.8 (8-C), 131.0 (9-C), 128.9 (6-C), 110.4 (7-C), 110.1 (4-C), 82.3 (5'-C), 67.0 (3'-C), 56.1 (17'-C), 55.4 (14'-C), 54.9 (7'-C), 54.4 (9'-C), 45.6 (13'-C), 45.3 (12'-C), 44.6 (24'-C), 42.4 (10'-C), 39.6 ( $\left.8^{\prime}-\mathrm{C}\right), 39.4$ (4'-C), 36.2 (22'-C), 35.5 (20'-C), 31.3 (1'-C), 29.7 (16'-C), 28.4 (25'-C), 28.0 (15'-C), 24.2 (2'-C), 23.8 (23'-C), 22.8 (26'-C), 22.5 (27'-C), 21.7 (11'-C), 18.8 (21'-C), 17.7 (18'-C), 12.5 (19'-C); HREIMS m/z: $552.3805[\mathrm{M}+\mathrm{H}]^{+}$(calcd. for $\mathrm{C}_{33} \mathrm{H}_{50} \mathrm{~N}_{3} \mathrm{O}_{4}, 552.3801$ ).

2-(3 $\beta^{\prime}$-Acetoxy-5 $\beta^{\prime}$-hydroxy-6'-B-norcholesteryl)-5-nitrobenzimidazole (8b) Yellow oil, yield: $41 \%$. IR (KBr) $v / \mathrm{cm}^{-1}: 3428,2945,1706,1615,1517,1467,1337,1253,1068,1018 ;{ }^{1} \mathrm{H} \mathrm{NMR}\left(\mathrm{CDCl}_{3}\right.$, $600 \mathrm{MHz}) \delta: 0.63\left(3 \mathrm{H}, \mathrm{s}, 18^{\prime}-\mathrm{CH}_{3}\right), 0.80\left(3 \mathrm{H}, \mathrm{d}, J=6.6,26^{\prime}-\right.$ or $\left.27^{\prime}-\mathrm{CH}_{3}\right), 0.81\left(3 \mathrm{H}, \mathrm{d}, J=6.6,26^{\prime}-\right.$ or $\left.27^{\prime}-\mathrm{CH}_{3}\right), 0.87\left(3 \mathrm{H}, \mathrm{d}, J=6.6,21^{\prime}-\mathrm{CH}_{3}\right), 1.06\left(3 \mathrm{H}, \mathrm{s}, 19^{\prime}-\mathrm{CH}_{3}\right), 1.93\left(3 \mathrm{H}, \mathrm{s}, 3^{\prime}-\mathrm{COCH}_{3}\right), 2.26(1 \mathrm{H}, \mathrm{q}$, $\left.J=11.4, \mathrm{C} 8^{\prime}-\mathrm{H}\right), 2.88\left(1 \mathrm{H}, \mathrm{d}, J=11.4, \mathrm{C}^{\prime}-\mathrm{H}\right), 3.53(1 \mathrm{H}, \mathrm{br} \mathrm{s},-\mathrm{OH}), 5.04-5.00\left(1 \mathrm{H}, \mathrm{m}, \mathrm{C} 3^{\prime}-\mathrm{H}\right), 7.53$ $\left(1 \mathrm{H}\right.$, br s, 7-ArH), $8.10(1 \mathrm{H}, \mathrm{dd}, J=8.4,1.8,6-\mathrm{ArH}), 8.45(1 \mathrm{H}$, br s, $4-\mathrm{ArH}) ;{ }^{13} \mathrm{C} \mathrm{NMR}\left(\mathrm{CDCl}_{3}, 75 \mathrm{MHz}\right)$ $\delta$ : 170.6 (3'-C=O ), 168.2 (2-C), 143.3 (5-C), 143.2 (8-C), 133.3 (9-C), 118.1 (6-C), 110.5 (7-C), 109.7 (4-C), 81.7 (5'-C), 69.9 (3'-C), 55.6 (17'-C), 55.4 (14'-C), 54.7 (7'-C), 54.6 (9'-C), 45.2 (13'-C), 45.1 (12'-C), 44.5 (24'-C), 39.6 (10'-C), 39.4 ( $\left.8^{\prime}-\mathrm{C}\right), 39.3$ (4'-C), 36.1 (22'-C), 35.5 (20'-C), 32.6 (1'-C), 28.4 (16'-C), 28.3 (25'-C), 28.0 (15'-C), 25.3 (2'-C), 23.8 (23'-C), 22.8 (26'-C), 22.5 (27'-C), 21.9 ( $\left.\mathrm{CH}_{3} \mathrm{CO}\right)$,

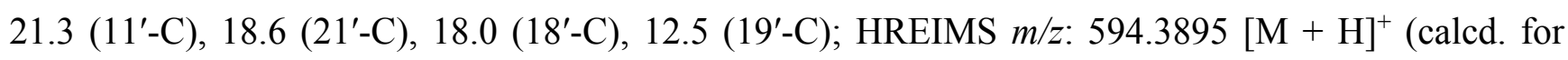
$\left.\mathrm{C}_{35} \mathrm{H}_{52} \mathrm{~N}_{3} \mathrm{O}_{5}, 594.3907\right)$. 
2-(3 $\beta^{\prime}, 5 \beta^{\prime}$-Dihydroxy-6'-B-norcholesteryl)benzimidazole (9a) Colourless oil, yield: 40\%; IR (KBr) $v / \mathrm{cm}^{-1}: 3385,2946,2863,1615,1524,1463,1415,1353,1063,1021 ;{ }^{1} \mathrm{H}$ NMR $\left(\mathrm{CDCl}_{3}, 300 \mathrm{MHz}\right) \delta$ : $0.65\left(3 \mathrm{H}, \mathrm{s}, 18^{\prime}-\mathrm{CH}_{3}\right), 0.86\left(1 \mathrm{H}, \mathrm{d}, J=6.6,26^{\prime}-\right.$ and $\left.27^{\prime}-\mathrm{CH}_{3}\right), 0.93\left(1 \mathrm{H}, \mathrm{d}, J=6.3,21^{\prime}-\mathrm{CH}_{3}\right), 1.13(1 \mathrm{H}$, s, 19'-CH3), $2.77\left(1 \mathrm{H}, \mathrm{d}, J=10.5, \mathrm{C}^{\prime}-\mathrm{H}\right), 4.07-3.99\left(1 \mathrm{H}, \mathrm{m}, \mathrm{C} 3^{\prime}-\mathrm{H}\right), 7.24$ (2H, dd, $J=6.0,3.0,5-\mathrm{ArH}$ and 6-ArH), 7.59 (2H, br s, 4-ArH and 7-ArH); ${ }^{13} \mathrm{C} \mathrm{NMR}\left(\mathrm{CDCl}_{3}, 75 \mathrm{MHz}\right) \delta$ : 169.2 (2-C), $155.4(8-\mathrm{C}$ and 9-C), 122.4 (5-C and 6-C), 122.2 (4-C and 7-C), 82.3 (5'-C), 67.1 (3'-C), 56.2 (17'-C), 55.5 (14'-C), 54.5 (7'-C), 53.9 (9'-C), 45.7 (13'-C), 45.3 (12'-C), 44.7 (24'-C), 42.8 (10'-C), 39.7 (8'-C), 39.4 (4'-C), 36.2 (22'-C), 35.6 (20'-C), 30.7 (1'-C), 29.7 (16'-C), 28.5 (25'-C), 28.0 (15'-C), 23.8 (2'-C), 22.8 (23'-C), 22.7 (26'-C), 22.6 (27'-C), 21.7 (11'-C), 18.8 (21'-C), 17.9 (19'-C), 12.5 (18'-C); HREIMS $m / z: 507.3965[\mathrm{M}+\mathrm{H}]^{+}$(calcd. for $\mathrm{C}_{33} \mathrm{H}_{51} \mathrm{~N}_{2} \mathrm{O}_{2}, 507.3951$ ).

2-(3 $\beta^{\prime}$-Acetoxy-5 $\beta^{\prime}$-hydroxy-6'-B-norcholesteryl)benzimidazole (9b) White solid, yield: 63\%, m.p.: 160-162 ${ }^{\circ} \mathrm{C}$. IR (KBr) $v / \mathrm{cm}^{-1}: 3451,2945,1714,1614,1526,1454,1362,1265,1023,1023,958 ;{ }^{1} \mathrm{H}$ NMR $\left(\mathrm{CDCl}_{3}, 600 \mathrm{MHz}\right) \delta: 0.63\left(3 \mathrm{H}, \mathrm{s}, 18^{\prime}-\mathrm{CH}_{3}\right), 0.83\left(1 \mathrm{H}, \mathrm{d}, J=6.6,26^{\prime}-\right.$ or $\left.27^{\prime}-\mathrm{CH}_{3}\right), 0.84(1 \mathrm{H}, \mathrm{d}$, $J=6.6,26^{\prime}-$ or $\left.27^{\prime}-\mathrm{CH}_{3}\right), 0.89\left(1 \mathrm{H}, \mathrm{d}, J=6.3,21^{\prime}-\mathrm{CH}_{3}\right), 1.08\left(1 \mathrm{H}, \mathrm{s}, 19^{\prime}-\mathrm{CH}_{3}\right), 1.93(1 \mathrm{H}, \mathrm{s}$, $\left.3^{\prime}-\mathrm{CH}_{3} \mathrm{CO}\right), 2.06\left(1 \mathrm{H}, \mathrm{d}, J=13.2, \mathrm{C}^{\prime}-\mathrm{H}\right), 2.21\left(1 \mathrm{H}, \mathrm{q}, J=10.8, \mathrm{C}^{\prime}-\mathrm{H}\right), 2.82\left(1 \mathrm{H}, \mathrm{d}, J=11.4, \mathrm{C} 7^{\prime}-\mathrm{H}\right)$, 5.01-4.95 (1H, m, C3'-H), 7.21-7.19 (2H, m, 5-ArH and 6-ArH), 7.55 (2H, br s, 4-ArH and 7-ArH); ${ }^{13} \mathrm{C} \mathrm{NMR}\left(\mathrm{CDCl}_{3}, 75 \mathrm{MHz}\right) \delta: 170.9$ (3'-C=O), 170.6 (2-C), 154.7 (8-C and 9-C), 122.4 (5-C and 6-C), 122.1 (4-C and 7-C), 81.3 (5'-C), 70.0 (3'-C), 55.8 (17'-C), 55.4 (14'-C), 54.9 (7'-C), 54.4 (9'-C), 45.1 (13'-C), 44.9 (12'-C), 44.5 (24'-C), 39.7 (10'-C), 39.4 (8'-C), 39.3 (4'-C), 36.2 (22'-C), 35.5 (20'-C), 32.9 (1'-C), 28.5 (16'-C), 28.0 (25'-C), 25.4 (15'-C), 23.9 (2'-C), 23.8 (23'-C), 22.8 (26'-C), 22.5 (27'-C), 21.9 ( $\left.\mathrm{CH}_{3} \mathrm{CO}\right), 21.4$ (11'-C), 18.8 (21'-C), 18.1 (19'-C), 12.5 (18'-C); HREIMS m/z: 549.4054 $[\mathrm{M}+\mathrm{H}]^{+}$(calcd. for $\left.\mathrm{C}_{35} \mathrm{H}_{53} \mathrm{~N}_{2} \mathrm{O}_{3}, 549.4056\right)$.

2-(3 $\beta^{\prime}, 5 \beta^{\prime}$-Dihydroxy-6'-B-norcholesteryl)-5, 6-dimethylbenzimidazole (10a) Brownish oil, yield: $77 \%$. IR (KBr) v/cm ${ }^{-1}: 3429,2945,1634,1534,1464,1377,1232,1018 ;{ }^{1} \mathrm{H} \mathrm{NMR}\left(\mathrm{CDCl}_{3}, 600 \mathrm{MHz}\right)$ $\delta: 0.63\left(3 \mathrm{H}, \mathrm{s}, 18^{\prime}-\mathrm{CH}_{3}\right), 0.85\left(3 \mathrm{H}, \mathrm{d}, J=6.6,26^{\prime}-\right.$ or $\left.27^{\prime}-\mathrm{CH}_{3}\right), 0.86\left(3 \mathrm{H}, \mathrm{d}, J=6.6,26^{\prime}-\right.$ or $\left.27^{\prime}-\mathrm{CH}_{3}\right)$, $0.91\left(3 \mathrm{H}, \mathrm{d}, J=6.0,21^{\prime}-\mathrm{CH}_{3}\right), 1.08\left(3 \mathrm{H}, \mathrm{s}, 19^{\prime}-\mathrm{CH}_{3}\right), 2.11-2.04\left(2 \mathrm{H}, \mathrm{m}, \mathrm{C} 4^{\prime}-\mathrm{H}\right.$ and $\left.\mathrm{C} 8^{\prime}-\mathrm{H}\right), 2.34(6 \mathrm{H}, \mathrm{s}$, 5- $\mathrm{CH}_{3}$ and 6- $\left.-\mathrm{CH}_{3}\right), 2.71\left(1 \mathrm{H}, \mathrm{d}, J=10.8, \mathrm{C}^{\prime}-\mathrm{H}\right), 3.86\left(1 \mathrm{H}\right.$, br s, $\left.\mathrm{C}_{3}-\mathrm{H}\right), 7.34(2 \mathrm{H}, \mathrm{br}$ s, $4-\mathrm{ArH}$ and 7-ArH); ${ }^{13} \mathrm{C} \mathrm{NMR}\left(\mathrm{CDCl}_{3}, 150 \mathrm{MHz}\right) \delta$ : 154.8 (2-C), 132.3 (5-C), 130.9 (6-C), 128.0 (8-C and 9-C), 118.6 (4-C and 7-C), 82.2 (5'-C), 67.0 (3'-C), 56.3 (17'-C), 55.5 (14'-C), 54.7 (7'-C), 54.4 (9'-C), 45.6 (13'-C), 45.2 (12'-C), 44.6 (24'-C), 42.6 (10'-C), 39.7 (8'-C), 39.5 (4'-C), 36.2 (22'-C), 35.5 (20'-C), 31.5 (1'-C), 28.5 (2'-C), 28.0 (16'-C), 24.2 (25'-C), 23.8 (15'-C), 22.8 (26'-C), 22.5 (27'-C), 21.7 (23'-C), 20.3 (11'-C), 18.9 (5- $\mathrm{CH}_{3}$ and 6- $\left.\mathrm{CH}_{3}\right), 18.8$ (21'-C), 17.7 (19'-C), 12.5 (18'-C ); HREIMS m/z: $535.4270[\mathrm{M}+\mathrm{H}]^{+}$(calcd. for $\mathrm{C}_{35} \mathrm{H}_{55} \mathrm{~N}_{2} \mathrm{O}_{2}, 535.4264$ ).

2-(3 $\beta^{\prime}$-Acetoxy-5 $\beta^{\prime}$-hydroxy-6'-B-norcholesteryl)-5, 6-dimethylbenzimidazole (10b) White solid, yield: $63 \%$, m.p.: $218-219^{\circ} \mathrm{C}$. IR (KBr) v/cm ${ }^{-1}: 3274,2942,1729,1534,1465,1359,1237,1018 ;{ }^{1} \mathrm{H}$ NMR $\left(\mathrm{CD}_{3} \mathrm{OD}, 300 \mathrm{MHz}\right) \delta: 0.74\left(3 \mathrm{H}, \mathrm{s}, 18^{\prime}-\mathrm{CH}_{3}\right), 0.86\left(6 \mathrm{H}, \mathrm{d}, J=6.6,26^{\prime}-\right.$ and $\left.27^{\prime}-\mathrm{CH}_{3}\right), 0.94(3 \mathrm{H}, \mathrm{d}$, $\left.J=6.3,21^{\prime}-\mathrm{CH}_{3}\right), 1.07\left(3 \mathrm{H}, \mathrm{s}, 19^{\prime}-\mathrm{CH}_{3}\right), 1.96\left(1 \mathrm{H}, \mathrm{s}, 3^{\prime}-\mathrm{CH}_{3} \mathrm{CO}\right), 2.12-2.03\left(2 \mathrm{H}, \mathrm{m}, \mathrm{C}^{\prime}-\mathrm{H}\right.$ and C8'-H), $2.35\left(6 \mathrm{H}, \mathrm{s}, 5-\mathrm{CH}_{3}\right.$ and 6- $\left.\mathrm{CH}_{3}\right), 2.80\left(1 \mathrm{H}, \mathrm{d}, J=11.7, \mathrm{C}^{\prime}-\mathrm{H}\right), 5.14-5.05\left(1 \mathrm{H}, \mathrm{m}, \mathrm{C}_{3}-\mathrm{H}\right), 7.29(2 \mathrm{H}, \mathrm{s}$, 4-ArH and 7-ArH); ${ }^{13} \mathrm{C} \mathrm{NMR}\left(\mathrm{CD}_{3} \mathrm{OD}, 150 \mathrm{MHz}\right) \delta$ : $171.1\left(3^{\prime}-\mathrm{C}=\mathrm{O}\right), 153.6(2-\mathrm{C}), 130.4$ (5-C, 6-C, 8-C and 9-C), 114.0 (4-C and 7-C), 80.8 (5'-C), 69.8 (3'-C), 55.8 (17'-C), 55.4 (14'-C), 54.4 (7'-C), 53.8 (9'-C), 44.5 (13'-C), 44.1 (12'-C), 43.8 (24'-C), 39.8 (10'-C), 39.2 (8'-C), 38.5 (4'-C), 36.0 (22'-C), 
35.5 (20'-C), 32.4 (1'-C), 28.2 (2'-C), 27.7 (16'-C), 25.0 (25'-C), 23.5 (15'-C), 23.3 ( CH $\left._{3} \mathrm{CO}\right), 21.8$

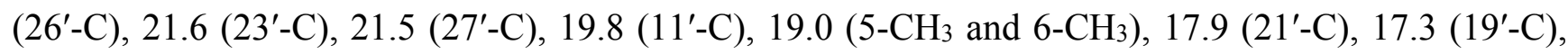
11.5 (18'-C); HREIMS m/z: $577.4390[\mathrm{M}+\mathrm{H}]^{+}$(calcd. for $\mathrm{C}_{37} \mathrm{H}_{57} \mathrm{~N}_{2} \mathrm{O}_{3}, 577.4369$ ).

2-(3 $\beta^{\prime}, 5 \beta^{\prime}$-Dihydroxy-6'-B-norcholesteryl)-5-methoxybenzimidazole (11a) Brownish oil, yield: 49\%. IR (KBr) $v / \mathrm{cm}^{-1}: 3420,2942,1629,1516,1452,1377,1198,1152,1028 ;{ }^{1} \mathrm{H} \mathrm{NMR}\left(\mathrm{CDCl}_{3}, 300 \mathrm{MHz}\right)$ $\delta: 0.65\left(3 \mathrm{H}, \mathrm{s}, 18^{\prime}-\mathrm{CH}_{3}\right), 0.86\left(3 \mathrm{H}, \mathrm{d}, J=6.6,26^{\prime}-\right.$ or $\left.27^{\prime}-\mathrm{CH}_{3}\right), 0.87\left(3 \mathrm{H}, \mathrm{d}, J=6.6,26^{\prime}-\right.$ or $\left.27^{\prime}-\mathrm{CH}_{3}\right)$, $0.92\left(3 \mathrm{H}, \mathrm{d}, J=6.6,21^{\prime}-\mathrm{CH}_{3}\right), 1.10\left(3 \mathrm{H}, \mathrm{s}, 19^{\prime}-\mathrm{CH}_{3}\right), 2.16-2.05\left(2 \mathrm{H}, \mathrm{m}, \mathrm{C} 4^{\prime}-\mathrm{H}\right.$ and $\left.\mathrm{C} 8^{\prime}-\mathrm{H}\right), 2.71(1 \mathrm{H}$, $\left.\mathrm{d}, J=10.8, \mathrm{C}^{\prime}-\mathrm{H}\right), 3.83\left(3 \mathrm{H}, \mathrm{s}, 5-\mathrm{OCH}_{3}\right), 3.98-3.91\left(1 \mathrm{H}, \mathrm{m}, \mathrm{C}^{\prime}-\mathrm{H}\right), 6.85(1 \mathrm{H}, \mathrm{dd}, J=8.7,2.4, \mathrm{C} 6-\mathrm{H})$, $7.06(1 \mathrm{H}, \mathrm{s}, \mathrm{C} 4-\mathrm{H}), 7.44$ (1H, d, $J=8.7, \mathrm{C} 7-\mathrm{H}) ;{ }^{13} \mathrm{C} \mathrm{NMR}\left(\mathrm{CDCl}_{3}, 75 \mathrm{MHz}\right) \delta: 156.1$ (2-C), 155.3 (5-C), 155.2 (8-C), 130.1 (9-C), 120.4 (7-C), 111.53 (6-C), 111.52 (4-C), 82.2 (5'-C), 67.0 (3'-C), 56.2 $\left(17^{\prime}-\mathrm{C}\right), 55.8\left(-\mathrm{OCH}_{3}\right), 55.5\left(14^{\prime}-\mathrm{C}\right), 54.7$ (7'-C), 54.2 (9'-C), 45.6 (13'-C), $45.2\left(12^{\prime}-\mathrm{C}\right), 44.6$ (24'-C), 42.6 (10'-C), 39.7 (4'-C), 39.4 (8'-C), 36.2 (22'-C), 35.5 (20'-C), 31.2 (1'-C), 29.7 (2'-C), 28.5 (16'-C), 28.0 (25'-C), 24.2 (15'-C), 23.8 (23'-C), 22.8 (27'-C), 22.5 (26'-C), 21.7 (11'-C), 18.8 (21'-C), 17.8 (19'-C), 12.5 (18'-C); HREIMS m/z: $537.4057[\mathrm{M}+\mathrm{H}]^{+}$(calcd. for $\mathrm{C}_{34} \mathrm{H}_{53} \mathrm{~N}_{2} \mathrm{O}_{3}, 537.4056$ ).

2-(3 $\beta^{\prime}$-Acetoxy-5 $\beta^{\prime}$-hydroxy-6'-B-norcholesteryl)-5-methoxybenzimidazole (11b) Yellow solid, yield: 29\%, m.p.: $135-137{ }^{\circ} \mathrm{C}$. IR (KBr) v/cm ${ }^{-1}: 3456,2942,2863,1716,1629,1594,1486,1417,1372,798$; ${ }^{1} \mathrm{H}$ NMR $\left(\mathrm{CDCl}_{3}, 300 \mathrm{MHz}\right) \delta: 0.65\left(3 \mathrm{H}, \mathrm{s}, 18^{\prime}-\mathrm{CH}_{3}\right), 0.85\left(6 \mathrm{H}, \mathrm{d}, J=6.6,26^{\prime}-\right.$ or and $\left.27^{\prime}-\mathrm{CH}_{3}\right), 0.91$ $\left(3 \mathrm{H}, \mathrm{d}, J=6.3,21^{\prime}-\mathrm{CH}_{3}\right), 1.09\left(3 \mathrm{H}, \mathrm{s}, 19^{\prime}-\mathrm{CH}_{3}\right), 1.96\left(3 \mathrm{H}, \mathrm{s}, 3-\mathrm{COCH}_{3}\right), 2.20\left(1 \mathrm{H}, \mathrm{q}, J=6.3, \mathrm{C} 8^{\prime}-\mathrm{H}\right)$, $2.76\left(1 \mathrm{H}, \mathrm{d}, J=10.8, \mathrm{C}^{\prime}-\mathrm{H}\right), 3.68(1 \mathrm{H}, \mathrm{br} \mathrm{s},-\mathrm{OH}), 3.83\left(3 \mathrm{H}, \mathrm{s}, 5-\mathrm{OCH}_{3}\right), 5.01-4.93\left(1 \mathrm{H}, \mathrm{m}, \mathrm{C} 3^{\prime}-\mathrm{H}\right)$, $6.85(1 \mathrm{H}, \mathrm{dd}, J=8.7,2.1, \mathrm{C} 6-\mathrm{H}), 7.19\left(1 \mathrm{H}\right.$, br s, C4-H), $7.55\left(1 \mathrm{H}\right.$, br s, C7-H); ${ }^{13} \mathrm{C} \mathrm{NMR}\left(\mathrm{CDCl}_{3}\right.$, $75 \mathrm{MHz}) \delta$ : 170.7 (3'-C=O), 156.1 (2-C), 155.3 (5-C), 155.2 (8-C), 130.1 (9-C), 120.4 (7-C), 111.53 (6-C), 111.52 (4-C), 81.1 (5'-C), 70.0 (3'-C), 55.8 (17'-C), $55.7\left(-\mathrm{OCH}_{3}\right), 55.4\left(14^{\prime}-\mathrm{C}\right), 54.7$ (7'-C), 54.4 (9'-C), 45.1 (13'-C), 44.8 (12'-C), 44.5 (24'-C), 39.7 (10'-C), 39.4 (4'-C), 39.3 (8'-C), 36.2 (22'-C), 35.5 (20'-C), 32.8 (1'-C), 29.7 (2'-C), 28.5 (16'-C), 28.0 (25'-C), 25.4 (15'-C), 23.8 (23'-C), 22.8 (27'-C), 22.5 (26'-C), 21.9 ( $\left.\mathrm{CH}_{3} \mathrm{CO}\right), 21.4$ (11'-C), 18.8 (21'-C), 18.1 (19'-C), 12.5 (18'-C); HREIMS $m / z: 579.4162[\mathrm{M}+\mathrm{H}]^{+}$(calcd. for $\mathrm{C}_{36} \mathrm{H}_{55} \mathrm{~N}_{2} \mathrm{O}_{4}, 579.4142$ ).

3.1.2. Compounds 12a-12b Were Prepared Similarly According to the Procedure of 7-11, but Using 4-Trifluoromethyl-O-phenylenediamine as Reagent

$N$-(2'-amino-5'-trifluoromethyl)phenyl-3 $\beta$-hydroxy-B-norcholestano[7,5- $d] \quad$ isoxazolidine $\quad$ (12a) Brownish oil, yield: 40\%; IR (KBr) v/cm ${ }^{-1}$ : 3424, 2947, 1627, 1524, 1447, 1329, 1232, 1110, 931; ${ }^{1} \mathrm{H}$ NMR $\left(\mathrm{CDCl}_{3}, 300 \mathrm{MHz}\right) \delta: 0.66\left(3 \mathrm{H}, \mathrm{s}, 18-\mathrm{CH}_{3}\right), 0.87\left(6 \mathrm{H}, \mathrm{d}, J=6.6,26-\right.$ and $\left.27-\mathrm{CH}_{3}\right), 0.94(3 \mathrm{H}, \mathrm{d}$, $\left.J=6.3,21-\mathrm{CH}_{3}\right), 1.08\left(3 \mathrm{H}, \mathrm{s}, 19-\mathrm{CH}_{3}\right), 2.08(1 \mathrm{H}, \mathrm{d}, J=12.9, \mathrm{C} 6-\mathrm{H}), 2.17(1 \mathrm{H}, \mathrm{q}, J=10.8, \mathrm{C} 6-\mathrm{H})$, $2.79(1 \mathrm{H}, \mathrm{d}, J=10.5, \mathrm{C} 7-\mathrm{H}), 3.88(1 \mathrm{H}, \mathrm{br} \mathrm{s}, \mathrm{C} 3-\mathrm{H}), 4.30(1 \mathrm{H}, \mathrm{br} \mathrm{s},-\mathrm{OH}), 7.44(1 \mathrm{H}, \mathrm{d}, J=8.4,6-\mathrm{ArH})$, $7.60\left(1 \mathrm{H}\right.$, br s, 3-ArH), $7.88\left(1 \mathrm{H}\right.$, br s, 5-ArH); ${ }^{13} \mathrm{C} \mathrm{NMR}\left(\mathrm{CDCl}_{3}, 75 \mathrm{MHz}\right) \delta: 158.3(1-\mathrm{PhC}), 130.3$ (CF3), 126.7 (2-PhC), 124.7 (4-PhC), 124.2 (5-PhC), 123.1 (3-PhC), 119.1 (6-PhC), 82.5 (5-C), 70.0 (3-C), 56.1 (17-C), 55.3 (14-C), 55.1 (9-C), 54.7 (7-C) 45.8 (8-C), 45.3 (13-C), 44.6 (10-C), 42.3 (6-C), 39.5 (12-C), 39.4 (24-C), 36.2 (4-C), 35.5 (20-C), 31.6 (22-C), 29.7 (1-C), 28.4 (2-C), 28.3 (16-C), 28.0 (25-C), 24.2 (15-C), 23.7 (23-C), 22.8 (26-C), 22.5 (27-C), 21.7 (11-C), 18.8 (21-C), 17.5 (19-C), 12.4 (18-C); HREIMS m/z: $577.3902[\mathrm{M}+\mathrm{H}]^{+}$(calcd. for $\mathrm{C}_{34} \mathrm{H}_{50} \mathrm{~F}_{3} \mathrm{~N}_{2} \mathrm{O}_{2}, 577.3981$ ). 
$N$-(2'-amino-5'-trifluoromethyl)phenyl-3 $\beta$-acetoxy-B-norcholestano[7,5- $d] \quad$ isoxazolidine (12b) Yellow solid, yield: $87.8 \%$, m.p.: $155-157^{\circ} \mathrm{C}$. IR (KBr) v/ $\mathrm{cm}^{-1}: 3461,2948,2858,1711,1629,1527$, $1417,1362,1330,1263,1115,1052 ;{ }^{1} \mathrm{H} \mathrm{NMR}\left(\mathrm{CDCl}_{3}, 300 \mathrm{MHz}\right) \delta: 0.61\left(3 \mathrm{H}, \mathrm{s}, 18-\mathrm{CH}_{3}\right), 0.85(6 \mathrm{H}, \mathrm{d}$, $J=6.6,26-$ and $\left.27-\mathrm{CH}_{3}\right), 0.91\left(3 \mathrm{H}, \mathrm{d}, J=6.3,21-\mathrm{CH}_{3}\right), 1.10\left(3 \mathrm{H}, \mathrm{s}, 19-\mathrm{CH}_{3}\right), 1.86\left(3 \mathrm{H}, \mathrm{s}, \mathrm{COCH}_{3}\right)$, $2.28(2 \mathrm{H}, \mathrm{q}, J=10.8, \mathrm{C} 6-\mathrm{H}), 2.96(1 \mathrm{H}, \mathrm{d}, J=11.7, \mathrm{C} 7-\mathrm{H}), 3.38(1 \mathrm{H}, \mathrm{br} \mathrm{s},-\mathrm{NH}), 5.02-4.89(1 \mathrm{H}, \mathrm{m}$, C3-H), $7.45(1 \mathrm{H}, \mathrm{d}, J=8.4,6-\mathrm{ArH}), 7.74(1 \mathrm{H}, \mathrm{s}, 3-\mathrm{ArH}), 7.98\left(1 \mathrm{H}, \mathrm{br}\right.$ s, 5-ArH); ${ }^{13} \mathrm{C} \mathrm{NMR}\left(\mathrm{CDCl}_{3}\right.$, $75 \mathrm{MHz})$ \&: $170.6\left(\mathrm{COCH}_{3}\right), 157.3$ (1-PhC), $130.3\left(\mathrm{CF}_{3}\right), 126.7$ (2-PhC), 124.6 (4-PhC), 124.2 (5-PhC), 123.1 (3-PhC), 119.1 (6-PhC), 81.6 (5-C), 69.7 (3-C), 55.7 (17-C), 55.4 (14-C), 54.7 (9-C), 54.6 (7-C), 44.9 (8-C), 44.8 (10-C), 44.5 (13-C), 39.7 (6-C), 39.4 (12-C), 39.0 (24-C), 36.1 (22-C), 35.5 (20-C), 32.7 (4-C), 29.7 (1-C), 28.4 (16-C), 28.0 (25-C), 25.4 (2-C), 24.0 (15-C), 23.7 (23-C), 22.8 (26-C), 22.5 (27-C), 21.9 (11-C), 21.1 ( $\left.\mathrm{CH}_{3} \mathrm{CO}\right), 18.8$ (21-C), 18.2 (19-C), 12.4 (18-C); HREIMS m/z: $[\mathrm{M}+\mathrm{H}]^{+} 619.3996$ (calcd. for $\mathrm{C}_{36} \mathrm{H}_{54} \mathrm{~F}_{3} \mathrm{~N}_{2} \mathrm{O}_{3}, 619.4087$ ).

3.1.3. Compound $\mathbf{1 3}$ Was Prepared Similarly According to the Procedure of 7-11, but Using 2-Mercaptophenylamine as Reagent

2-(3 $\beta^{\prime}, 5 \beta^{\prime}$-Dihydroxy-6'-B-norcholesteryl)benzothiazole (13) Light yellow solid, yield: 55\%, m.p.: $180-182{ }^{\circ} \mathrm{C}$. IR (KBr) v/cm ${ }^{-1}: 3453,2920,2726,1674,1589,1462,1377,1165,1073,951 ;{ }^{1} \mathrm{H}$ NMR $\left(\mathrm{CDCl}_{3}, 300 \mathrm{MHz}\right) \delta$ : $0.69\left(3 \mathrm{H}, \mathrm{s}, 18^{\prime}-\mathrm{CH}_{3}\right), 0.87\left(3 \mathrm{H}, \mathrm{d}, J=6.6,26^{\prime}-\right.$ or $\left.27^{\prime}-\mathrm{CH}_{3}\right), 0.87(3 \mathrm{H}, \mathrm{d}, J=6.6$, $26^{\prime}-$ or $\left.27^{\prime}-\mathrm{CH}_{3}\right), 0.94\left(3 \mathrm{H}, \mathrm{d}, J=6.3,21^{\prime}-\mathrm{CH}_{3}\right), 1.13\left(3 \mathrm{H}, \mathrm{s}, 19^{\prime}-\mathrm{CH}_{3}\right), 2.14-2.06\left(2 \mathrm{H}, \mathrm{m}, \mathrm{C} 4{ }^{\prime}-\mathrm{H}\right), 2.25$ $\left(1 \mathrm{H}, \mathrm{q}, J=10.8, \mathrm{C} 8^{\prime}-\mathrm{H}\right), 3.04\left(1 \mathrm{H}, \mathrm{d}, J=9.6, \mathrm{C} 7^{\prime}-\mathrm{H}\right), 3.30(1 \mathrm{H}$, br s, $-\mathrm{OH}), 3.95(1 \mathrm{H}, \mathrm{s},-\mathrm{OH})$, 4.10-4.04 (1H, m, C3'-H), 7.37 (1H, td, $J=8.1,1.5,5-\mathrm{ArH}), 7.47$ (1H, td, $J=7.8,1.5,6-\mathrm{ArH}), 7.85$ $(1 \mathrm{H}, \mathrm{d}, J=7.5,4-\mathrm{ArH}), 7.99(1 \mathrm{H}, \mathrm{d}, J=7.8,7-\mathrm{ArH}) ;{ }^{13} \mathrm{C} \mathrm{NMR}\left(\mathrm{CDCl}_{3}, 75 \mathrm{MHz}\right) \delta: 173.1$ (2-C), 153.4 (8-C), 134.5 (9-C), 126.0 (5-C), 124.7 (6-C), 122.7 (7-C), 121.4 (4-C), 83.2 (5'-C), 67.1 (3'-C), 58.3 (17'-C), 56.8 (14'-C), 55.5 (7'-C), 51.8 (9'-C), 47.2 (13'-C), 45.3 (8'-C), 44.8 (12'-C), 44.1 (24'-C), 39.7 $\left(10^{\prime}-\mathrm{CH}_{2}\right), 39.5$ (4'-C), 36.2 (22'-C), 35.6 (20'-C), 28.9 (1'-C), 28.5 (2'-C), 28.4 (16'-C), 28.0 (25'-C), 24.7 (15'-C), 23.8 (23'-C), 22.8 (27'-C), 22.5 (26'-C), 21.6 (11'-C), 18.8 (21'-C), 18.2 (19'-C), 12.5 $\left(18^{\prime}-\mathrm{C}\right)$; HREIMS $m / z$ : $524.3562[\mathrm{M}+\mathrm{H}]^{+}$(calcd. for $\mathrm{C}_{33} \mathrm{H}_{50} \mathrm{NO}_{2} \mathrm{~S}, 524.3562$ ).

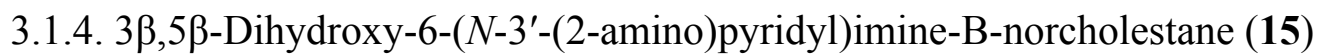

Compound $\mathbf{1 5}$ was prepared similarly according to the procedure of $\mathbf{7 - 1 1}$, but using 2,3-diaminopyridine as reagent.

Brown oil, Yield: 49\%. IR (KBr) v/cm ${ }^{-1}: 3454,2920,1716,1671,1589,1462,1377,1165,1073$, 1013; ${ }^{1} \mathrm{H}$ NMR $\left(\mathrm{CDCl}_{3}, 300 \mathrm{MHz}\right) \delta: 0.67\left(3 \mathrm{H}, \mathrm{s}, 18-\mathrm{CH}_{3}\right), 0.84\left(6 \mathrm{H}, \mathrm{d}, J=6.9,26-\right.$ and $\left.27-\mathrm{CH}_{3}\right), 0.90$ $\left(3 \mathrm{H}, \mathrm{d}, J=6.3,21-\mathrm{CH}_{3}\right), 0.95\left(3 \mathrm{H}, \mathrm{s}, 19-\mathrm{CH}_{3}\right), 2.35-2.30(1 \mathrm{H}, \mathrm{m}, \mathrm{C} 7-\mathrm{H}), 3.38(1 \mathrm{H}, \mathrm{s},-\mathrm{OH}), 4.12-4.07$ $\left(1 \mathrm{H}, \mathrm{m}, \mathrm{C}_{3}-\mathrm{H}\right), 4.34\left(2 \mathrm{H}\right.$, br s, $\left.-\mathrm{NH}_{2}\right), 5.00(1 \mathrm{H}, \mathrm{s},-\mathrm{OH}), 6.52\left(1 \mathrm{H}, \mathrm{dd}, J=7.5,5.1,5^{\prime}-\mathrm{PhH}\right), 6.94(1 \mathrm{H}$, $\left.\mathrm{dd}, J=7.5,1.5,4^{\prime}-\mathrm{PhH}\right), 7.77\left(1 \mathrm{H}, \mathrm{dd}, J=5.1,1.2,6^{\prime}-\mathrm{PhH}\right), 7.85(1 \mathrm{H}, \mathrm{d}, J=6.6, \mathrm{C} 6-\mathrm{H}) ;{ }^{13} \mathrm{C}$ NMR $\left(\mathrm{CDCl}_{3}, 75 \mathrm{MHz}\right) \delta$ : 170.7 (6-C), 153.2 (2-PhC), 144.4 (6-PhC), 133.5 (3-PhC), 125.0 (4-PhC), 113.8 (5-PhC), 84.3 (5-C), 66.7 (3-C), 60.4 (17-C), 59.4 (14-C), 56.2 (7-C) 55.6 (9-C), 51.4 (13-C), 45.5 (10-C), 44.7 (8-C), 44.1 (12-C), 42.6 (24-C), 39.7 (4-C), 39.4 (22-C), 36.2 (20-C), 35.6 (1-C), 28.5 
(2-C), 28.0 (16-C), 24.9 (25-C), 23.8 (15-C), 22.8 (26-C), 22.6 (27-C), 21.7 (23-C), 21.0 (11-C), 18.8 (21-C), 14.2 (19-C), 12.5 (18-C); HREIMS m/z: $510.4090[\mathrm{M}+\mathrm{H}]^{+}$(calcd. for $\mathrm{C}_{32} \mathrm{H}_{52} \mathrm{~N}_{3} \mathrm{O}_{2}, 510.4060$ ).

\subsection{Biological Assays}

\subsubsection{Materials}

Stock solutions of the compounds were prepared in sterile dimethyl sulfoxide (DMSO) (Sigma, St. Louis, MO, USA) at a concentration of $10 \mathrm{mg} / \mathrm{mL}$ and afterward diluted with complete nutrient medium (RPMI-1640) supplemented with $10 \%$ heat inactivated fetal bovine serum and $0.1 \mathrm{~g} / \mathrm{L}$ penicillin $\mathrm{G}+0.1 \mathrm{~g} / \mathrm{L}$ streptomycin sulfate.

\subsubsection{Cell Culture}

HeLa, A549, HEPG2 cancer cells and HEK293T cells were grown in the medium (RPMI-1640) supplemented with $10 \%$ heat inactivated fetal bovine serum and $0.1 \mathrm{~g} / \mathrm{L}$ penicillin $\mathrm{G}+0.1 \mathrm{~g} / \mathrm{L}$ streptomycin sulfate in a humidified atmosphere of $5 \% \mathrm{CO}_{2}$ at $37{ }^{\circ} \mathrm{C}$.

\subsubsection{Assay for Cell Viability}

The anticancer activity in vitro was measured using the MTT assay. Briefly, cells $\left(1 \sim 2 \times 10^{4}\right.$ cells per well) were seeded in 96-wells plates for $24 \mathrm{~h}$. Different concentrations of the test compound were added to the cells. An equal amount of DMSO was added to the cells used as negative controls. Triplicate wells were prepared for each individual dose. After reincubated for $72 \mathrm{~h}$, the cells were washed with sterile phosphate buffer saline (PBS). $190 \mu \mathrm{L}$ of RPMI-1640 and $10 \mu \mathrm{L}$ of the tetrazolium dye (MTT) $(5 \mathrm{mg} / \mathrm{mL})$ solution were added to each well, and the cells were incubated for additional $4 \mathrm{~h}$. After the supernatant was discarded, $200 \mu \mathrm{L}$ of DMSO was added to dissolve the purple formazan crystals formed. The absorbance values $(A)$ at $492 \mathrm{~nm}$ were determined using a MLLTISKAN MK3 analysis spectrometer (Thermo Scientific, Shanghai, China). The $\mathrm{IC}_{50}$ values were calculated as the concentration of drug yielding 50\% cell survival.

\subsubsection{Annexin V Staining Assay}

Apoptosis was detected with an annexin V-FITC kit purchased from BD Pharmingen (San Diego, CA, USA) according to the manufacturer's instructions. HeLa cells were seeded in $35 \mathrm{~mm}$ culture dishes and allowed to attach overnight. The cells were treated with 9b, 10a and 11a for $24 \mathrm{~h}$, respectively, collected, and washed twice with PBS. To detect early and late apoptosis, both adherent and floating cells were harvested together and resuspended in annexin $\mathrm{V}$ binding buffer at a concentration of $10^{6}$ cells $/ \mathrm{mL}$. Subsequently, $5 \mu \mathrm{L}$ of FITC-conjugated annexin $\mathrm{V}$ and $5 \mu \mathrm{L}$ of propidium iodide were added to $100 \mu \mathrm{L}$ of the cell suspension $\left(10^{5}\right.$ cells $)$. The cells were incubated for $15 \mathrm{~min}$ at room temperature in the dark. Finally, $400 \mu \mathrm{L}$ of annexin V binding buffer was added to each tube, and cells were analyzed by a two-color cytometry using FACS Calibur flow cytometry (Becton Dickinson, Biosciences, Franklin Lakes, NJ, USA). 


\section{Conclusions}

We synthesized some novel B-norcholesteryl benzimidazole and benzothiazole derivatives. The antiproliferative activity of the compounds against human cervical carcinoma (HeLa), human lung carcinoma (A549), human liver carcinoma cells (HEPG2) and normal kidney epithelial cells (HEK293T) was assayed. The results showed that some B-norcholesteryl benzimidazole compounds exhibited an excellent antiproliferative activity and almost inactive to normal kidney epithelial cells (HEK293T). In addition, the results revealed that the benzimidazole group was a better substituent than benzothiazole group for increasing the antiproliferative activity of compounds. The most potent compound $9 \mathbf{b}$ with the structure of 6-benzimidazole exhibited excellent antiproliferative activities with an $\mathrm{IC}_{50}$ value of 4.7, 11.9 and $4.2 \mu \mathrm{M}$ against HeLa, A549 and HEPG2 cells, respectively, and was able to effectively induce tumor cells apoptotic. The results suggest that B-norcholesteryl derivatives based on benzimidazole group may constitute a novel class of antiproliferative agents, which deserve further study.

\section{Acknowledgments}

The authors acknowledge the financial support of the National Natural Science Foundation of China (No: 21462009) and the Foundation of Guangxi Key Laboratory of Beibu Gulf Marine Biodiversity Conservation, Qinzhou University (No: 2015ZA01).

\section{Author Contributions}

Y.M. Huang was responsible for the natural science foundation of China (No:21462009). J.G. Cui conceived the design of synthetic route and was responsible for the guidance of all synthetic experiments. B.B. Qi, Q.F. Lin and D.D. Zhao synthetized B-norcholesteryl Benzimidazole and Benzothiazole Derivatives. Z.P. Liu and H. Huang screened cell lines in vitro. C.F. Gan performed the apoptotic experiment.

\section{Conflicts of Interest}

The authors declare no conflict of interest.

\section{References}

1. World Health Organization. The Global Burden of Disease: 2004 Update; World Health Organization: Geneva, Switzerland, 2008.

2. Jemal, A.; Siegel, R.; Ward, E.C.A. Cancer Statistics, 2010. Cancer J. Clin. 2010, 60, 277-300.

3. Miyamoto, T.; Kodama, K.; Aramaki, H.Y.R.; van Soest, R.W.M. Orostanal, a novel abeo-sterol inducing apoptosis in leukemia cell from a marine sponge, Stelletta hiwasaensis. Tetrahedron Lett. 2001, 42, 6349-6351.

4. Wei, X.; Rodríguez, A.D.; Wang, Y.; Franzblau, S.G. Novel ring B abeo-sterols as growth inhibitors of Mycobacterium tuberculosis isolated from a Caribbean Sea sponge, Svenzea zeai. Tetrahedron Lett. 2007, 48, 8851-8854. 
5. Gan, C.F.; Fan, L.H.; Cui, J.G.; Huang, Y.M.; Jiao, Y.X.; Wei, W.X. Synthesis and in vitro antiproliferative evaluation of some ring B abeo-sterols. Steroids 2012, 77, 1061-1068.

6. Gan, C.F.; Fan, L.H.; Huang, Y.M.; Liu, Z.P.; Cui, J.G. Synthesis of novel ring B abeo-sterol derivatives and their antiproliferative activities. Med. Chem. 2013, 9, 846-854.

7. Gan, C.F.; Lin, Q.F.; Cui, J.G.; Feng, J.D.; Guo, J.N.; Liao, H.Y.; Huang, Y.M. Synthesis and in vitro antiproliferative evaluation of some novel B-norcholesterols. Steroids 2014, 79, 37-43.

8. Singh, H.; Kapoor, V.K.; Paul, D. Heterosteroids and drug research. In Progress in Medicinal Chemistry; Ellis, G.P., West, G.B., Eds.; Springer: Amsterdam, The Netherlands, 1979; Volume 16, pp. 35-150.

9. Singh, H.; Jindal, D.P.; Yadav, M.R.; Kumar, M. Heterosteroids and drug research. In Progress in Medicinal Chemistry; Ellis, G.P., West, G.B., Eds.; Elsevier science publishers: Amsterdam, The Netherlands, 1991; Volume 28, pp. 233-300.

10. Lakhani, N.J.; Sarkar, M.A.; Venitz, J.; Figg, W.D. 2-Methoxyestradiol, a promising anticancer agent. Pharmacotherapy 2003, 23, 165-172.

11. Carlini, P.; Frassoldati, A.; Marco, S.D.; Casali, A.; Ruggeri, E.M.; Nardi, M.; Papaldo, P.; Fabi, A.; Paoloni, F.; Cognetti, F. Formestane, a steroidal aromatase inhibitor after failure of non-steroidal aromatase inhibitors (anastrozole and letrozole): Is a clinical benefit still achievable? Ann. Oncol. 2001, 12, 1539-1543.

12. Simpson, D.; Wagstaff, A.J. Estramustine Phosphate Sodium. Am. J. Can. 2003, 2, 373-390.

13. Attard, G.; Reid, A.H.M.; Yap, T.A.; Raynaud, F.; Dowsett, M.; Settatree, S.; Barrett, M.; Parker, C.; Martins, V.; Folkerd, E.; et al. Phase I Clinical trial of a selective inhibitor of CYP17, abiraterone acetate, confirms that castration-resistant prostate cancer commonly remains hormone driven. J. Clin. Oncol. 2008, 26, 4563-4571.

14. Cui, J.G.; Liu, L.; Gan, C.F.; Xiao, Q.; Huang, Y.M. Recent progress in synthesis and biological activity of steroids bearing aromatic rings and heterocycles. Progress Chem. 2014, 26, 320-333.

15. Ma, B.; Xiao, Z.Y.; Chen, Y.J.; Lei, M.; Meng, Y.H.; Guo, D.A.; Liu, X.; Hu, L.H. Synthesis and structure activity relationships study of cytotoxic bufalin 3-nitrogen-containing-ester derivatives. Steroids 2013, 78, 508-512.

16. Guo, H.; Zhang, G.L.; Zhang, T.; He, X.R.; Wu, Z.Y.; Xiao, Y.L.; Pan, Y.H.; Qiu, G.F.; Liu, P.; $\mathrm{Hu}$, X.M. Synthesis, characterization and biological evaluation of some 16b-azolyl-3bamino-5aandrostane derivatives as potential anticancer agents. Eur. J. Med. Chem. 2011, 46, 3662-3674.

17. Huang, L.H.; Zheng, Y.F.; Lu, Y.Z.; Song, C.J.; Wang, Y.G.; Yu, B.; Liu, H.M. Synthesis and biological evaluation of novel steroidal[17,16-d][1,2,4]triazolo [1,5-a]pyrimidines. Steroids $\mathbf{2 0 1 2}$, 77, 710-715.

18. Kovács, D.; Mótyán, G.; Wölfling, J.; Kovács, I.; Zupkó, I.; Frank, É. A facile access to novel steroidal 17-2'-(1',3',4')-oxadiazoles, and anevaluation of their cytotoxic activities in vitro. Bioorg. Med. Chem. Lett. 2014, 24, 1265-1268.

19. Zhang, B.L.; Zhang, E.; Pang, L.P.; Song, L.X.; Li, Y.F.; Yu, B.; Liu, H.M. Design and synthesis of novel D-ring fused steroidal heterocycles. Steroids 2013, 78, 1200-1208.

20. Liu, B.; Zhou, W.S. The first stereoselective synthesis of orostanal isolated from a marine sponge Stelletta hiwasaensis. Tetrahedron 2003, 59, 3379-3384. 
21. Wentworth, P., Jr.; Nieva, J.; Takeuchi, C.; Galve, R.; Wentworth, A.D.; Dilley, R.B.; DeLaria, G.A.; Saven, A.; Babior, B.M.; Janda, K.D.; et al. Evidence for ozone formation in human atherosclerotic arteries. Science 2003, 302, 1053.

22. Natalie, K.C.; Johanna, C.S.; Terry, D.B.; Wentworth, P., Jr. Adduction of cholesterol 5,6-secosterol aldehyde to membrane-bound myelin basic protein exposes an immunodominant epitope. Biochemistry 2011, 50, 2092-2100.

23. Lin, S.N.; Yang, L.H. A simple and efficient procedure for the synthesis of benzimidazoles using air as the oxidant. Tetrahedron Lett. 2005, 46, 4315-4319.

(C) 2015 by the authors; licensee MDPI, Basel, Switzerland. This article is an open access article distributed under the terms and conditions of the Creative Commons Attribution license (http://creativecommons.org/licenses/by/4.0/). 